\title{
BDNF-TrkB signaling as a therapeutic target in neuropsychiatric disorders
}

This article was published in the following Dove Press journal:

Journal of Receptor, Ligand and Channel Research

6 October 2014

Number of times this article has been viewed

\author{
Xin $\mathrm{Du}^{\prime}$ \\ Yeewen C Wu ${ }^{1,2}$ \\ Rachel Anne Hill' \\ 'Florey Institute for Neuroscience \\ and Mental Health, University of \\ Melbourne, Parkville, VIC, Australia; \\ ${ }^{2}$ Department of Pharmacology, \\ University of Melbourne, Parkville, \\ VIC, Australia
}

Correspondence: Rachel Anne Hill Florey Institute for Neuroscience and Mental Health, University of Melbourne, Kenneth Myer Building, Royal Pde, Parkville, Victoria, 3010, Australia Tel +6I 39035666 I

Email rachel.hill@florey.edu.au

\begin{abstract}
Research evidence points to abnormal brain-derived neurotrophic factor (BDNF) signaling being a common and vital participant in the etiology and pathophysiology of many psychiatric disorders, including depression, schizophrenia, and bipolar disorder. To increase BDNF levels in patients is therefore a necessary goal of any treatment. This review explores the various therapeutic strategies that can increase BDNF brain expression and recover mental health disturbances. From environmental enrichment and exercise to dietary intake, it is apparent that a healthy lifestyle significantly influences BDNF signaling and mental health. We conclude that in order to combat the inefficiency of current treatment methods, more attention should be focused on holistic approaches to achieve this goal, as BDNF is proven to have dynamic responses to environmental influences.
\end{abstract}

Keywords: BDNF, neurotrophins, mental health

\section{Introduction}

Neurotrophins are a family of growth-factor proteins that promote the survival, growth, maturation, and function of neurons. The family of neurotrophins to which brain-derived neurotrophic factor (BDNF) belongs also contains nerve-growth factor (NGF), neurotrophin 3, and neurotrophin 4. ${ }^{1,2}$ Of these, BDNF is especially assiduous and plethoric; its importance is shown by its highly conserved structure ${ }^{3}$ and by early postnatal lethality in knockout mouse models. ${ }^{4}$

Since its identification more than three decades ago, ${ }^{5}$ BDNF has been found to be vital during embryonic brain development, where it is seminal in early synaptic and neuronal circuit formation..$^{6-9}$ Its importance also persists postnatally, where it supports neuronal maturation, homeostasis, and survival, ${ }^{4,10,11}$ the regulation of synaptic transmission and neuronal plasticity, ${ }^{12-14}$ and the promotion of neurogenesis via enhancing the proliferation, ${ }^{15-17}$ differentiation, ${ }^{18}$ and survival $1{ }^{19}$ of newborn cells.

The $B D N F$ gene is mapped to chromosome 11p in humans and exhibits highly complex regulation of its expression. It has been found to have eleven exons and nine functional promoters that direct tissue, brain-region, and cellular spatial specificity. ${ }^{20,21}$ BDNF is synthesized as a $35 \mathrm{kDa}$ prepro isoform, which may then be cleaved to form a $28 \mathrm{kDa}$ proBDNF or a $13.5 \mathrm{kDa}$ mature BDNF. The expression of BDNF is regulated via neuronal activity through calcium-mediated mechanisms, ${ }^{22}$ and its high-affinity tyrosine kinase-coupled receptor, the tropomyosin-related kinase receptor (TrkB), is also regulated in an activity-dependent manner. ${ }^{23}$ BDNF also binds with a low affinity to the 75 receptor, which it shares with other members of the neurotrophin family. The 
mature BDNF isoform has a high affinity for TrkB, and upon binding activates a number of intracellular signaling pathways including phosphoinositide 3-kinase, phospholipase $\mathrm{C} \gamma$, and mitogen-activated protein kinase ${ }^{24}$ While it is thought that the pro or truncated BDNF isoform has little biological activity, preproBDNF is thought to form a complex with sortilin and p75 to elicit apoptotic signaling. ${ }^{25}$

Having so many fundamental and diverse influences on the brain naturally led to the linkage of abnormal BDNF expression and function with various psychiatric diseases. ${ }^{26-31}$ One crucial reason is the finding that stress, a great inducer of depression, anxiety, and other psychiatric problems, impairs BDNF and TrkB signaling in limbic areas critically associated with emotionality, such as the hippocampus and frontal cortex. ${ }^{32-35}$ This review focuses on the pathophysiological involvement of BDNF in psychiatric disorders, the therapeutic potential of this prolific growth factor, and the various methods in which restoration of BDNF signaling may be implemented.

\section{BDNF and depression}

Depression is a multifarious and debilitating disorder that is among the top three contributors to the global burden of disease. ${ }^{36,37}$ It is also a disease whose prevalence is on a sharp upward trend. ${ }^{36,38}$ Depression is a major contributor to suicide $^{39}$ and is often a symptom of or highly comorbid with other neurological disorders, such as schizophrenia, ${ }^{40}$ Alzheimer's disease, ${ }^{41}$ Parkinson's disease, ${ }^{42-44}$ and Huntington's disease, ${ }^{45-47}$ as well as with major diseases such as type 2 diabetes, ${ }^{48}$ cardiovascular disease,${ }^{49-51}$ and alcohol withdrawal syndrome, ${ }^{52}$ to name but a few.

Depression is thought to result from an inability of the brain to make appropriate adjustments and adaptations in response to environmental stressors, due to impaired or inadequate synaptic and neural plasticity. ${ }^{53-56}$ This is evidenced by studies showing altered brain structures in depressed patients, such as reductions in cell number, cell density, and body size as well as reduced glial density in frontal cortical and hippocampal brain regions. ${ }^{57-60}$ These observations led to the hypothesis that a loss of neurotrophic factors, which are essential for the survival, development, and maintenance of neurons ${ }^{61,62}$ and for regulating synaptic and morphological plasticity, ${ }^{1,63}$ is directly involved in the pathophysiology of depression and that its restitution may lie at the heart of successful treatment - the neurotrophin theory of depression. ${ }^{27,35,53,64}$ BDNF, an essential, abundant, and prolific neurotrophin conspicuous for its relationship to various neurological and psychiatric disorders, has been given particular interest.
The link between BDNF and depression has been shown by a wealth of evidence. A common single-nucleotide polymorphism in the BDNF gene at nucleotide 196 (G/A), which causes a valine (Val)-to-methionine (Met) substitution at codon 66 (Val66Met) has been shown to negatively affect memory and induce abnormal hippocampal activity as well as to disrupt normal activity-dependent BDNF secretion ${ }^{65}$ and dendritic trafficking of BDNF mRNA. ${ }^{66}$ Those with the Met allele also show reduced hippocampal and prefrontal cortex gray matter volume. ${ }^{65,67}$ A recent meta-analysis suggests that the Met allele is associated with increased susceptibility to stressful life events and subsequent depression. ${ }^{68}$ Another study observed a correlation between having the Met allele and increased chronicity of depression with a gene-dosage effect - Val/Met heterozygotes show intermediate chronicity between Val/Val and Met/Met homozygotes, who showed the highest chronicity. ${ }^{69}$ These findings suggest that disruptions in BDNF signaling increase the propensity to depression.

BDNF can cross the blood-brain barrier, ${ }^{70}$ and its serum protein levels in the periphery are strongly correlated with protein concentrations in the central nervous system. ${ }^{71}$ Levels of peripheral BDNF measured in serum and plasma have largely been found to be significantly reduced in patients suffering depression and dysthymia disorder, compared with healthy people. ${ }^{72-74}$ A significant negative correlation between BDNF levels and the severity of symptoms according to the Hamilton Rating Scale for Depression ${ }^{75}$ as well as the Montgomery-Åsberg Depression Rating Scale ${ }^{76}$ have also been observed, suggestive of a dose effect. Going hand-inhand, successful treatment seems to correlate with the restitution of BDNF. Serum BDNF was found to be significantly lower in antidepressant-naïve depressed patients than in healthy controls, whereas patients treated with antidepressants showed a significant elevation in BDNF when compared with nonmedicated patients. ${ }^{77,78}$ A recent meta-analysis confirmed reduced serum BDNF in antidepressant-free depressed patients versus healthy controls and antidepressant-treated patients, but failed to find the correlation between BDNF concentration and symptom severity. ${ }^{79}$ Indeed, systematic analysis in more than a thousand patients did not find any association between decreased BDNF and specific symptoms or symptom clusters. ${ }^{80}$

In postmortem samples, both mRNA and protein expression of BDNF and its receptor TrkB were found to be reduced in the prefrontal cortex and hippocampus of suicide victims. ${ }^{81,82}$ Hippocampal BDNF levels were found to be higher in both patients with major depression and suicide victims treated with antidepressants at time of death, 
compared with untreated subjects. ${ }^{82,83}$ Tying in with this are the neuroimaging studies that have found reductions in frontal-lobe ${ }^{84,85}$ and hippocampal volume in depressed patients, which correlated negatively with duration of disease. ${ }^{86-88}$ Within a cohort of patients suffering major depression, who exhibited overall reduced hippocampal volumes compared with controls, those with the Met allele had significantly smaller hippocampal volume than patients with the Val allele. ${ }^{89}$ Hippocampal shrinkage is attenuated in patients undergoing antidepressant treatment. ${ }^{90,91}$ Likewise, a recovery in dorsal-lateral prefrontal cortical volume was seen in patients after antidepressant treatment and was correlated with a self-reported decrease in depression level. ${ }^{92}$ Orbitofrontal cortex shrinkage ${ }^{93}$ was partially attenuated in geriatric patients with depression who had used antidepressants versus those who were drug-naïve. ${ }^{94} \mathrm{~A}$ direct positive correlation has also been found via magnetic resonance imaging (MRI) between serum BDNF levels and hippocampal volume of first-episode, medication-free depressed patients, ${ }^{95}$ suggestive of BDNF's importance in the etiology and pathogenesis of depression. Despite some inconsistencies between neuroanatomical studies, most likely due to sample differences in illness severity, medication, sex, family history, et cetera, ${ }^{96}$ the evidence nevertheless suggests that antidepressants arrest brain atrophy and symptom deterioration at least partly by increasing BDNF levels.

This supposition is further fortified by research in rodent models, where a mouse model containing the Met/Met allele exhibited abnormally increased anxiety-like behaviors when confronted by stressful settings, was unresponsive to fluoxetine treatment, and showed decreased hippocampal volume and reduced BDNF secretion, reflective of clinical data. ${ }^{97}$ In rodents, early life stress (a model of depression) lowered BDNF and altered stress sensitivity later in life, ${ }^{98}$ whereas increases in BDNF, either via social enrichment or direct infusion into the brain, reduced susceptibility to depression-like behaviors. ${ }^{99-101}$ However, studies also found that increases in BDNF through communal nesting induced a depressive-like phenotype by increasing immobility time in the forced-swim test. ${ }^{102}$ Other studies examining the role of BDNF in depression have also found that heterozygous knockout of BDNF did not alter anxiety as tested on the elevated-plus maze. ${ }^{103-105} B D N F$ heterozygote mice and mice expressing the dominant negative TrkB receptor TrkB.T1 did not show any differences compared with wild-type mice in their performance on the forced-swim test, therefore suggesting that reduced BDNF signaling alone may not be sufficient to cause depression per se. ${ }^{106}$
There is accumulating evidence suggesting inflammation as a mediator of the pathophysiology of mood disorders. ${ }^{107,108}$ Many studies show that depression is often accompanied by an activation of the inflammatory response system, with an increased production of proinflammatory cytokines. Two meta-analyses consisting of 24 studies and 29 studies, respectively, have shown that interleukin (IL)-6, and tumor necrosis factor (TNF)- $\alpha$ are increased in patients with major depression compared with controls, ${ }^{109,110}$ the 2012 study also reported increased soluble IL-2 receptor levels in depressed patients. Cytokine administration has similar effects as psychogenic stressors through actions in the hypothalamus and limbic areas, making it a candidate in the pathophysiology of depression. ${ }^{111}$ It has been suggested that the depressive effects of an increased inflammatory response is an adaptive change to encourage individuals to rest and reserve energy as the body combats disease. ${ }^{112}$ The effect of inflammatory factors on BDNF is rather scant, but studies have shown that IL- $1 \beta$ and TNF- $\alpha$ can decrease BDNF mRNA in the amygdala of rats. ${ }^{113}$ Interferon- $\alpha$ has been found to reduce BDNF in humans, ${ }^{114,115}$ as does lipopolysaccharide in rats. ${ }^{116}$ IL-1 $\beta$ has also been shown to reduce BDNF-TrkB signaling and to interfere with BDNF-induced antiapoptotic effects. ${ }^{117}$ However, another study found that IL-1 $\beta$ increased BDNF mRNA expression in rat hypothalamic neuron-enriched cultures while it reduced BDNF expression in mixed neuronastrocyte cultures. ${ }^{118}$ Inflammatory cytokines also attenuated TrkB phosphorylation, thereby interfering with BDNF signaling. ${ }^{119}$ Counterbalancing this, imipramine's ability to offer neuroprotection against lipopolysaccharide-induced apoptosis requires intact BDNF signaling. ${ }^{120}$ The evidence therefore hints at a complex relationship, but one that could potentially compromise BDNF signaling.

Collectively, these findings suggest that BDNF may be a key molecule involved in various antidepressant treatment strategies. Therefore, restitution of BDNF may be a fundamental goal of treatments targeting depression.

\section{BDNF and schizophrenia}

It has been suggested that altered synthesis and/or release of neurotrophins may contribute to the development of schizophrenia. ${ }^{29,30,121}$ Studies on post-mortem tissue from patients with schizophrenia showed a significant reduction in both $B D N F$ and TrkB transcripts as well as BDNF protein in the dorsolateral prefrontal cortex, compared with controls. ${ }^{122-124}$ Another study, measuring protein concentrations determined by enzyme linked immunosorbent assay (ELISA), showed decreased BDNF levels in the hippocampus 
but increased BDNF levels in the neocortex and unchanged BDNF levels in the cingulate gyrus and thalamus of schizophrenia patients. ${ }^{125}$ In contrast, other studies examining the hippocampus of schizophrenia patients showed increased immunostaining of BDNF and TrkB proteins ${ }^{126}$ and increased BDNF protein but decreased TrkB protein, as measured by ELISA and Western blots, respectively. ${ }^{127}$ It is unclear why there are these opposite and inconsistent findings between studies, although different methods used to measure BDNF and TrkB could be responsible. For example, ELISA methods, used in the aforementioned studies, typically cannot differentiate between pro and mature BDNF isoforms, while Western blotting can distinguish the two. However, more recently, selective ELISA kits have become available that are advertised to be specific to either mature BDNF (human BDNF ELISA Kit; Adipo Bioscience, Santa Clara, CA, USA) or proBDNF (human proBDNF ELISA Kit; Adipo Bioscience). Indeed, a recent study using the above-mentioned ELISA kits demonstrated a selective reduction in mature but not proBDNF isoforms in patients with major depressive disorder, ${ }^{73}$ demonstrating the importance of assessing these isoforms individually.

Most studies show significantly reduced serum BDNF protein levels in chronic and medicated patients with schizophrenia compared with healthy controls. ${ }^{128-132}$ This is also true in first-episode and antipsychotic-naive patients with schizophrenia compared with healthy people. ${ }^{133-135}$ However, increased BDNF serum protein levels have also been reported, ${ }^{136}$ while other studies have failed to find any significant differences. ${ }^{137,138}$ Komulainen et al ${ }^{139}$ reported that a reduction in plasma BDNF protein levels was associated with cognitive impairment in a large sample of women aged 57-79 years, but not in men. Further, women who reported using sex hormones (hormone-replacement therapy) performed better in tests of general cognition, memory, and executive function. ${ }^{139}$ Taken together, clinical data point to a dysregulation of BDNF signaling in schizophrenia. ${ }^{140}$

The dopamine hypothesis of schizophrenia suggests that schizophrenia is caused by excessive dopaminergic neurotransmission, and consequently, most antipsychotic medications act via dopamine receptor DR2 antagonism. BDNF has been shown to play a critical role in the developmental expression of dopamine receptor DR3 in the nucleus accumbens. ${ }^{141}$ Conversely, striatal BDNF expression may be altered by activation of dopamine receptors DR1 and DR2. ${ }^{142}$ Hence, a strong relationship appears to exist between BDNF and dopamine' signaling, and alterations to either of these systems may underlie the pathophysiology of schizophrenia and may dictate responsiveness to antipsychotic medication.
Indeed, medication-naïve patients have been shown to have lower plasma BDNF levels, suggesting a role for antipsychotics in the regulation of BDNF. ${ }^{143}$ This positive effect of antipsychotics on BDNF expression is specific to atypical antipsychotics, as typical antipsychotics such as haloperidol tend to reduce BDNF expression levels. ${ }^{143-145}$ However, this tends to be antipsychotic-specific, as a cross sectional survey demonstrated positive effects of clozapine, but not risperidone, on serum BDNF levels. ${ }^{146}$

Both in vitro and in vivo studies have shown a positive effect of atypical antipsychotics, such as olanzapine and lurasidone, on BDNF mRNA and protein expression in the prefrontal cortex and hippocampus. ${ }^{147,148}$ Thus alterations in the levels of BDNF may represent one of the mechanisms by which antipsychotics exert their effects.

Several studies have shown an association between the Val66Met $B D N F$ polymorphism and aspects of schizophrenia, including age of onset, ${ }^{149}$ antipsychotic response, ${ }^{150-152}$ and cognitive function. ${ }^{153,154}$ Both patients with schizophrenia and healthy participants carrying the Met allele showed poorer verbal memory than their Val homozygous counterparts. ${ }^{155}$ However, the Met allele was associated with visuospatial impairments that were specific to schizophrenia patients but not healthy participants. ${ }^{155}$ A 2012 meta-analysis of the association between the Val66Met polymorphism and cognition, including 23 studies up to 2010, reported no significant associations with the polymorphism and measures of general cognitive ability, memory, executive function, visual processing skills, and cognitive fluency. ${ }^{156}$ These discrepancies in the literature may be due to limited sample sizes, lack of consistency in the cognitive tasks assessed, or other hidden sources of variation such as ethnicity of the subjects (the frequency of the derivative allele ranges from near $0 \%$ in Africans to up to $60 \%$ in Asians and $17 \%$ in Caucasians). ${ }^{156}$ In addition, it may be that the polymorphism renders the patient more vulnerable to stress-induced disruption (eg, gene $\times$ environment). For example, Met carriers exposed to high childhood abuse showed significantly poorer cognitive function when compared with Val carriers, ${ }^{157}$ suggesting a gene $\times$ environment interaction. This gene $\times$ environment interaction has been further explored in our laboratory, where we have shown in $B D N F$ heterozygous mice that an additional environmental insult in the form of chronic corticosterone treatment leads to significant impairments in spatial memory. ${ }^{158}$

Cognitive impairments have also been reported in conditional $B D N F$ knockout mice. For instance, a conditional dorsal hippocampus $B D N F$ deletion in male mice impairs spatial learning in the Morris Water Maze and nonspatial 
recognition memory in novel-object recognition tests. ${ }^{24,159}$ Interestingly, Monteggia et al ${ }^{160}$ found a sex-specific behavioral phenotype in mice with forebrain-specific $B D N F$ deletions. The female conditional knockout mice exhibited normal locomotor activity but a substantial increase in depression-like behaviors, whereas male conditional knockouts showed hyperactivity but normal depression-related behaviors. Other animal models of schizophrenia have also displayed alterations in BDNF expression levels, including rat models induced by postnatal MK-801 or phencyclidine administration, ${ }^{161,162}$ disrupted in schizophrenia 1 (DISC-1) and Reelin mutant mouse models, ${ }^{163,164}$ and a prenatal infection (poly-I:C) mouse model. ${ }^{165}$

Cytokines have been posited to play a role in schizophrenia. ${ }^{166}$ A comprehensive meta-analysis showed that schizophrenia is associated with altered cytokine profiles. IL-1 $\beta$, IL-6, and transforming growth factor (TGF)- $\beta$ all are increased in both acute relapse patients and first-episode patients; this abnormal increase was abolished by antipsychotic treatment. On the other hand, IL-12, interferon- $\gamma$, TNF- $\alpha$, and soluble IL-2 receptor were found to be elevated and remained elevated following antipsychotic treatment, ${ }^{167}$ suggesting that IL-1 $\beta$, IL-6, and TGF- $\beta$ are good state markers. Furthermore, another study found increased IL-6 and TNF- $\alpha$ in first-episode psychotic patients. Linear regression showed that increased psychosocial stress predicted lower BDNF through an inflammation-mediated pathway and that the increased IL-6 correlated with reductions in BDNF and left hippocampal volume. ${ }^{168}$

Together, the studies above suggest that BDNF may underlie aspects of positive symptoms such as hyperactivity and cognitive dysfunction as well as negative symptoms associated with schizophrenia.

\section{BDNF and bipolar disorder}

Bipolar disorder is a devastating psychiatric condition marked with severe mood symptoms, most notoriously by episodes of mania or hypomania typically followed by an episode of depressed mood. Lifetime prevalence stands between $1 \%-4 \% .{ }^{169}$ Genetic studies show bipolar disorder is highly heritable, explaining about $60 \%-85 \%$ of variance in risk. ${ }^{170}$ Relatives of a bipolar sufferer have a significantly increased risk of developing bipolar disorder as well as unipolar major depression disorder. ${ }^{170,171}$

$B D N F$ has been posited as a key candidate gene associated with the etiology of bipolar disorder. A metaanalysis of 14 studies found a significant association between the Val66Met allele and bipolar disorder. ${ }^{172}$ A recent study showed that serum BDNF levels in drug-free bipolar patients suffering either a manic or depressive episode were reduced compared with healthy controls. ${ }^{173}$ This is in agreement with a meta-analysis that found reduced serum and plasma BDNF levels in both manic and depressive patients, with an association with the length of illness. It was also found that peripheral BDNF increased after treatment for acute mania, suggesting that BDNF can be a marker for mood episodes. ${ }^{174}$ A recent study comparing BDNF levels in first major depressive episode patients suffering either from bipolar or major depression found that while both groups showed significantly reduced plasma BDNF, those suffering bipolar disorder had even lower BDNF levels than did the major depression patients. ${ }^{175}$ However, other studies found either no decrease in plasma BDNF in patients compared with controls ${ }^{176}$ or even an increase in plasma BDNF compared with controls. ${ }^{177}$ One study found that improvement in symptoms resulting from quetiapine treatment was accompanied by increases in BDNF in patients with depressive episodes and decreases in BDNF in patients with manic or mixed episodes, ${ }^{178}$ suggesting differential BDNF alteration according to polarity of disease, adding a layer of complexity in analyzing the role of $\mathrm{BDNF}$.

Postmortem analysis found reduced BDNF mRNA expression in layer VI in the inferior temporal gyrus and layers V and VI of the superior temporal gyrus in patients with bipolar disorder, schizophrenia, or major depression disorder. ${ }^{179}$ Hippocampal proBDNF levels were also found to be reduced in postmortem bipolar samples to a similar but slightly lesser degree than that of major depression disorder samples. ${ }^{180}$ MRI revealed decreased gray matter in bipolar sufferers compared with controls, but there were no differences between Val66 versus Met66 allele carriers. ${ }^{181}$

Examining cytokine profiles in bipolar patients in the depressed, manic, and euthymic phases, Brietzke et $\mathrm{al}^{182}$ found different state-dependent profiles. Manic phase was associated with increases in IL-2, IL-4, and IL-6 compared with controls; patients in depression phase exhibited an increase only in IL-6; euthymic patients show an upregulation in IL-4 only, suggesting that change in cytokine expression profile is a good state marker in bipolar disorder. Looking at early versus late-stage bipolar patients, it was found that BDNF was only reduced in the late stages of disease despite increased IL-6, IL-10, and TNF- $\alpha$ levels at the early phase of disease. A significant negative correlation was seen between BDNF and TNF- $\alpha$, which continued to increase in the late stages of disease, whereas IL- 6 and IL-10 decreased in late-stage patients. ${ }^{183}$ However, it was found in adolescent bipolar 
patients that a negative association exists between BDNF and IL-6, ${ }^{184}$ suggesting negative influences of increased cytokine on BDNF signaling even in early phases of disease.

The evidence suggests that an important role is played by BDNF in mediating both the pathogenesis and symptom severity of bipolar disorder.

\section{Antidepressants and BDNF}

In addition to its role in synaptic plasticity, the BDNF signaling pathway is now well known to interact with the serotonergic system at several different levels. A recent review by Homberg et $\mathrm{al}^{185}$ suggests that alterations to the serotonin (5-HT) transporter in 5-HT transporter knockout rats reduced BDNF mRNA and protein expression in both the hippocampus and prefrontal cortex, and this reduction in BDNF may then alter 5-HT1A receptor signaling. In addition, we have shown an upregulation of BDNF protein in the hippocampus of 5-HT2C receptor knockout male mice, ${ }^{186}$ but a decrease in BDNF protein and TrkB phosphorylation (activation) in the ventral hippocampus of 5-HT1A receptor knockout mice, and this was specific to female mice. ${ }^{187}$ With this complex interplay between BDNF and the serotonin pathway in mind, it is not surprising then that BDNF is thought to play a role in mediating antidepressant drug effects.

BDNF seems to mediate the positive effect of several classes of antidepressants, including selective serotonin reuptake inhibitors, tricyclics, serotonin noradrenalin reuptake inhibitors, and monoamine oxidase inhibitors, which have been found to increase BDNF in patient serum, cortical astrocytes in vitro, and in the prefrontal cortex and hippocampus of animal models. ${ }^{77,188,189}$ Gervasoni et al ${ }^{190}$ found that not only was reduced BDNF in depressed patients was increased following antidepressants, but in both instances BDNF negatively correlated with depression severity as measured by the Montgomery-Asberg Depression Rating Scale. Chen et $\mathrm{al}^{83}$ also found increased BDNF immunoreactivity in the hilus, dentate gyrus, and supragranular zone of postmortem patients on antidepressants at the time of death compared with those who were not on antidepressants.

Rodent models allow closer dissection of the mechanism of antidepressants and further illuminate the importance of BDNF in mediating antidepressant effects. In rats, Nibuya et al ${ }^{191,192}$ found that chronic but not acute treatment with various antidepressants including sertraline, desipramine, and tranylcypromine increased the gene expression of $B D N F$ and TrkB in different subregions of the hippocampus, including the granule cell layer, CA1, and CA3; this effect was not found using nonantidepressant psychotrophs such as haloperidol and cocaine. Furthermore, chronic antidepressant treatment was also protective against the reduction of BDNF and TrkB induced by restraint stress. In forebrain BDNFdeficient mice, the antidepressant and learning-enhancing effects of desipramine were abolished. ${ }^{106,193}$ Transgenic mice overexpressing the dominant negative truncated TrkB receptor TrkB.T1, which show reduced TrkB activation in the brain, are resistant to the effects of antidepressants, ${ }^{106}$ whereas overexpression of TrkB led to resistance to depression-like behavior, with selective serotonin reuptake inhibitors unable to further increase this resistance. ${ }^{194}$ TrkB agonists have been found to exert antidepressive effects in rodents, ${ }^{195}$ indicating that TrkB signaling is necessary for the behavioral benefits of antidepressants.

\section{BDNF as a therapeutic target}

A key question in the treatment of depression with antidepressants has been why it takes weeks for antidepressants to achieve beneficial effects when they are able to alter synaptic monoamine levels within a matter of hours. It has been theorized that this delay is due to the time required to achieve neuroadaptive changes ${ }^{196,197}$ and that this action is mediated via BDNF. ${ }^{198-200}$ It is a well-known phenomenon that fewer than half of patients treated with antidepressants derive any benefit. ${ }^{201}$ Katsuki et $\mathrm{al}^{202}$ found that the difference between responders and nonresponders to treatment with mirtazapine is the ability for the antidepressant to increase serum BDNF. Hence, other means of elevating BDNF is greatly sought. Infusion of BDNF directly into the hippocampus ${ }^{101}$ or peripherally ${ }^{203}$ produces antidepressant-like effects in mouse models. However, as a therapeutic or adjunctive treatment, peripherally administered BDNF is unsuitable due to: 1) the tumour promoting properties of BDNF; ${ }^{204} 2$ ) the limited ability of BDNF to cross the blood-brain barrier (which remains controversial); 3) poor bioavailability (due to enzyme degradation); ${ }^{205}$ and 4) short half-life (within hours, therefore requiring multiple doses). ${ }^{206}$ However, lifestyle alterations and diets including small molecules that can specifically activate the BDNF receptor are attractive candidates for potential therapeutic use.

\section{Environmental enrichment}

As $B D N F$ gene expression is triggered by neuronal activity; ${ }^{22}$ enhancement of cognitive and sensory stimulation has been posited as a way to enhance BDNF expression. Much work has been done in rodent models - the first description of positive effects of environmental enrichment (EE) was made by Donald Hebb, who let his rats roam 
free in his house and found that these rats performed better in problem-solving tests than rats kept in cages in the laboratory. ${ }^{207}$ While the ingredients of an enriched environment can differ greatly between laboratories and studies, what it essentially involves is a housing condition that promotes and enhances sensory, cognitive, and motor stimulation relative to standard housing. This is typically achieved through group housing in large boxes with the addition of various objects like tunnels, nesting material, and running wheels to the habitat. ${ }^{208,209}$

Further investigations in rodents unearthed that environmental enrichment can lead to increased cerebral volume ${ }^{210}$ as a result of increased cerebral cortical thickness, number of synapses and glial cells. ${ }^{211,212}$ It has long been known that detraction of environmental stimulation, such as social isolation housing, increases stress and promotes depressionlike behaviors. ${ }^{213,214}$ Being the negative corollary, EE has been found to have the opposite effects - anxiolytic and antidepressant-like actions - in a variety of rodent models of psychiatric and neurologic disorders. ${ }^{215-220}$ Enrichment promotes hippocampal cell proliferation and survival. ${ }^{221}$ In fact, it has been found that adult neurogenesis is required to facilitate EE benefits to counter depressive-like behaviors induced by psychosocial stress in mice. ${ }^{222}$ Furthermore, BDNF was seen as the intermediary of increased neurogenesis after EE, as $B D N F$ heterozygous mice that did not show any increase in BDNF after EE did not show any increase in neurogenesis, unlike their wild-type counterparts that showed both an increase in BDNF and a two-fold increase in neurogenesis. ${ }^{223}$ The positive behavioral effects of EE also correlate with increases in BDNF in the amygdala and hippocampus of rats. ${ }^{224} B D N F$ heterozygote mice exhibited increased anxiety and altered nociception, which were corrected by enrichment ${ }^{225}$ as well as increases in BDNF expression in the hippocampus. ${ }^{226}$ Neuropathic pain is common in psychiatric diseases and this may be due to increased inflammation, which exacerbates nociceptive sensitivity. ${ }^{227}$ $\mathrm{EE}$ has been shown to have immunomodulatory actions ${ }^{228}$ that counteract inflammation, which, in conjunction with increasing BDNF, may offer a double-pronged beneficial effect in combating depression.

Due to the multifaceted nature of environmental enrichment, it is difficult to untangle the essential key elements of enrichment to allow efficient clinical translation. Systematic clinical studies looking at the equivalent of environmental enrichment are comparatively scant compared with those studying effects of pharmacological treatments. Evidence does suggest that complementary interventions that foster social contact and mental and physical stimulation can have benefits to patients. A recent study found that the act of joining social groups had positive benefits on depression symptoms and decreased the risk of depression relapse in a dose-dependent manner. ${ }^{229}$ Similarly, social networking benefitted schizophrenia patients, with positive effects persisting long after implementation. ${ }^{230}$ Gentle yoga intervention was seen to benefit women suffering depression by enhancing connectedness. ${ }^{231}$ Likewise, patients who joined Argentine tango or meditation lessons showed a significant reduction on their depression measures. ${ }^{232}$ Massage and yoga also showed anxiolytic and antidepressant effects in prenatally depressed women. ${ }^{233}$ A review found an overall positive effect of massage treatment for depressed people despite large variations in effect size, most likely due to differences in the protocol used. ${ }^{234}$ In schizophrenia patients, a recent meta-analysis did not find convincing benefits of yoga. ${ }^{235}$ Little evidence is available on the effects of these therapies on BDNF expression.

More substantial studies have been performed in looking at music therapy. Psychodynamic music therapy has been found to reduce depression and anxiety symptoms ${ }^{236}$ as well as altering frontotemporal electroencephalograph activities in patients. ${ }^{237} \mathrm{~A}$ review concluded that chronic music listening can reduce depressive symptoms regardless of type of music preferred by the listener. ${ }^{238}$ Systematic review of music therapy in schizophrenia patients found general positive benefits on various aspects of the disease, including global state, general mental state, depression, anxiety, and negative symptoms, but effects were inconsistent and variable due to variability in protocols. ${ }^{239}$ Interestingly, rodent studies duplicated the effects of music observed in humans, with one study reporting that chronic exposure to a range of music, including vocal and instrumental (both Oriental and Western), had anxiolytic effects, which were accompanied by increases in BDNF mRNA and protein expression in the prefrontal cortex, hippocampus, and amygdala. ${ }^{240}$ Interestingly, the elevation of BDNF was seen in $B D N F$ (Met/Met) transgenic and wild-type mice but not in $B D N F$ heterozygous mice. Chronic exposure to slow rhythm music in mice has also been shown to increase BDNF levels in the hypothalamus ${ }^{241}$ and hippocampus as well as to enhance learning in the passive-avoidance task. ${ }^{242}$ As music has been demonstrated to stimulate areas of the brain associated with emotionality, such as the hypothalamus, hippocampus, amygdala, and prefrontal cortex, ${ }^{243}$ the evidence from rodent studies suggests that BDNF may be the mediator of the benefits of music on psychiatric disorders. 
Cognitive behavioral therapy (CBT) is a widespread behavioral approach in the treatment of psychiatric disorders. It has been found to show some efficacy in the treatment of depression $^{244}$ and schizophrenia. ${ }^{245}$ A meta-analysis however, showed dubious efficacy of CBT on schizophrenia but more robust effects on the treatment of major depression, both in reducing symptoms and preventing relapse. ${ }^{246}$ This opacity of CBT effect is due to a lack of controls available in studies looking at CBT, unlike the rigorous double-blind, placebo-controlled experiments used to scrutinize the efficacy of drugs.

Physical activity has always been considered an important part of an enriched life, and the majority of EE paradigms include running wheels. Studies have suggested that in fact physical exercise is the key element mediating positive benefits of EE on psychiatric disorders. Rodent studies have indeed found that the element of running is crucial to increasing neurogenesis and mature BDNF levels in the hippocampus, whereas enrichment without running wheels did not achieve these changes in female mice. ${ }^{247} \mathrm{~A}$ recent systematic study examining the different constituents of EE, separating out running, environmental complexity, and the social interaction elements, showed that running is the principal neurogenic stimulus. ${ }^{248}$ Complex environment, despite not increasing neurogenesis, did increase depolarizationassociated c-Fos expression in the granule cell layer and reduced stress-induced plasma corticosterone levels, which occurred regardless of running. These results suggest that while environmental complexity and social interaction have certain positive influences, physical exercise might be the prevailing mediator of BDNF upregulation and subsequent benefits.

\section{Exercise}

Exercise has been shown to have positive effects on depression, ${ }^{249-251}$ with levels of physical activity negatively correlated with depression symptoms. ${ }^{252}$ It was found that within a population of patients with major depression, those who are physically active show milder symptoms compared with more sedentary sufferers. ${ }^{253}$ Blumenthal et $\mathrm{al}^{254}$ found that group-supervised and individual home-based aerobic exercise were equally effective in getting patients into remission as was sertraline across 16 weeks of treatment, with milder side-effects in the exercise groups. Echoing this, a study in rats found chronic running-wheel housing increased BDNF mRNA level to a similar extent as chronic antidepressant treatment. Furthermore, a joint treatment of citalopram with running wheel resulted in a greater rise in
BDNF mRNA than either treatment alone, ${ }^{255}$ suggesting an additive or adjunctive effect.

Exercise has also been shown to impart benefits to schizophrenia patients, reducing both positive and negative symptoms, ${ }^{256-258}$ improving memory and increasing hippocampal volume, ${ }^{259}$ as well as increasing serum BDNF levels. ${ }^{260}$ Exercise was found to be associated with lower depressive symptoms but more manic symptoms in bipolar disorder. ${ }^{261}$ Evidence of a positive influence of exercise on schizophrenia and bipolar disorder are more scant compared with studies in depression. ${ }^{262} \mathrm{~A}$ recent study looked at the effect of a 4-week exercise regimen in patients with major depression or schizophrenia matched for age, sex, education, and disease duration. Despite the relatively short duration, the authors found benefits in both groups, with reduced depressive symptoms and anxiety in the depressed patients and reduced negative symptoms in schizophrenia patients. Both groups showed increases in cognitive function and increased subjective ratings on quality of life. ${ }^{263}$ The efficacy of physical exercise is difficult to gauge due to inconsistencies in regimens, types of exercises, and duration and frequency of exercises undertaken.

While the exact mechanism underlying the benefits of exercise is not understood, BDNF has been posited as a participant. Neeper et $\mathrm{al}^{264}$ first reported that acute exercise can increase hippocampal and caudal neocortical BDNF mRNA in rats. Following from this, evidence is found to show that similarly, a single bout of exercise can induce an acute if transient increase in serum or plasma BDNF in depressed patients. ${ }^{265,266}$ Subsequent training can augment this response, suggesting a mechanism to long-lasting benefits. ${ }^{267}$ However, differences in effect are seen in different regimens. For example, 3 months of endurance training at $70 \%$ maximum heart rate and $\sim 65 \%$ maximal oxygen uptake for an hour a day in healthy subjects was found to increase basal serum BDNF levels but to have no influence on exercise-induced BDNF levels. ${ }^{268}$ The same study found that a similar regimen in mice consisting of 5 weeks of 1-hour-long treadmill running, 5 days a week, led to an increase in hippocampal but not cortical BDNF mRNA expression. Another study instituted a 10-week strength-training regimen, after which no increase in either baseline or postexercise serum BDNF or in cognition was seen. ${ }^{269}$ Similarly, a 12-week training intervention of either moderate endurance training or high-load strength training, despite having positive endurance and strength augmentation, respectively, did not increase baseline plasma BDNF. ${ }^{270}$ Compared with this, a 5-week regimen of a mixture of moderate to intense endurance exercise induced in healthy 
young men an increase in both basal and exercise-induced plasma BDNF. This study also examined a cohort of athletes whose plasma BDNF was found to be about three times higher than that in untrained subjects. ${ }^{271}$

Ferris et $\mathrm{al}^{272}$ found that postexercise increases in serum BDNF were only achieved with a 30-minute bout of intense riding exercise at $10 \%$ above ventilator threshold and not after riding at $20 \%$ below the ventilator threshold. A recent study examined time as well as intensity of exercise and found that to achieve maximal postexercise increases in serum BDNF, a long duration (40 minutes as opposed to 20 minutes) of intense aerobic exercise ( $80 \%$ of heart rate reserve as opposed to $60 \%$ ) was the most effective. ${ }^{273}$ This evidence suggests a certain level of exercise intensity, duration, and chronicity is required to achieve reliable elevation of BDNF that might translate to therapeutic benefits. Consistent with this, it was found in a large cohort of women that those who reported a history of vigorous exercise had the lowest odds of depression symptoms, compared with more sedentary subjects. ${ }^{274}$ For patients treated for depression, regular exercise after cessation of initial pharmacotherapy or exercise regimen intervention showed benefit at follow-up months later, with the amount of exercise per week correlating negatively with Hamilton Rating Scale for Depression score and positively with the probability of partial remission. ${ }^{275,276}$ A very recent study examined effects of implementing a 3-month exercise regimen (3 sessions per week; 45 minutes per session) of aerobic exercise ( $80 \%$ maximum heart rate) versus control exercise (consisting of stretching and low-impact exercise such as catching and throwing balls) in outpatients with major depression. The study failed to find any increase in BDNF after the regimen, nor any change in hippocampal volume. However, this study suffered from poor adherence, with an average of only one attendance to exercise sessions per week instead of the planned three, making it hard to draw conclusions as to the effects of exercise on BDNF. ${ }^{277}$

In support of the clinical evidence, BDNF is found to be upregulated by exercise and environmental enrichment in rodents, contributing to beneficial effects such as induction of cell survival and proliferation and dendritic development, leading to augmented cognitive outcomes. ${ }^{278-282}$ Fang et $\mathrm{al}^{283}$ found that treadmill exercise in rats attenuated reductions in BDNF and phosphorylated TrkB in the hippocampus caused by chronic immobility stress. A recent study found that exercise, via running wheel, in rats compensated for high-fat diet-induced memory deficits measured in the two-way avoidance task and that this correction was associated with increases in BDNF expression in the CA3 subfield of the dorsal hippocampus. ${ }^{284}$ Intensity of exercise was also a factor, with higher intensity resulting in increased levels of BDNF in the hippocampus as well as increased cell proliferation in rats. ${ }^{285}$ In mice too, a 6-week voluntary running regimen in male $\mathrm{C} 57 \mathrm{Bl} / 6 \mathrm{~J}$ mice reduced anxiety-like behaviors and increased gene expression of $B D N F .^{286}$

The positive effects of exercise may be affected by myriad other factors. A Japanese study found that cycling for 30 minutes at $60 \%$ maximal oxygen uptake induced an increase in serum BDNF in 18/33 subjects, which, when aggregated, was not significant. The authors attributed the inconsistency to lifestyle and environmental idiosyncrasies. ${ }^{287}$ Another recent study conducted in Japan found that during 9 weeks of intense military training, despite increased physical activities as shown by serum levels of muscle enzymes creatine phosphokinase and lactate dehydrogenase, decreased plasma BDNF, which recovered 4-5 days after cessation of military training. ${ }^{288}$ This study attributed this decrease to reduced sleep quality as well as to stress and fatigue. This suggests that any benefits of exercise may be compromised by stress and fatigue. Interestingly, a study reported that the increase in BDNF resulting from cycling was negated in those cycling near a major road where air pollution was high. ${ }^{289}$ Agreeing with this, a recent Chinese study examining the effects of closure of a highly polluting coal-burning power plant found that babies born to mothers after the closure of the plant had reduced polycyclic aromatic hydrocarbons-adducts and increased BDNF compared with those born before the closure, highlighting the impact of pollution on developmental BDNF expression. ${ }^{290}$ Babaei et $\mathrm{al}^{291}$ indeed found that a 6-week endurance training regimen increased serum BDNF only in healthy subjects and not in subjects with metabolic syndrome. Metabolic syndrome, linked with unhealthy diet and lifestyle, is very prevalent in psychiatric illness ${ }^{292}$ and may be a factor preventing obvious benefits of exercise intervention. These studies suggest a multitude of environmental and lifestyle factors can influence the effect of exercise on BDNF expression.

\section{Healthy diet}

In 1988 Christensen and Christensen ${ }^{293}$ reported that the ratio of dietary saturated to polyunsaturated fat was a major predictor of outcome for schizophrenia. Animal model studies have shown that levels of BDNF, which are reduced in schizophrenia, have been shown to be reduced in the hippocampus of rats fed a high-fat, refined-sugar diet. ${ }^{294}$ This effect of a high-fat diet on hippocampal BDNF expression has recently been replicated and was also shown to disrupt performance in active-avoidance memory tasks. Furthermore, exercise recovered hippocampal BDNF and memory performance in rats 
fed a high-fat diet, suggesting that a combination of healthy diet and exercise are highly effective in regards to memory performance. ${ }^{284,295}$ A high-fat diet has also been shown to induce anxiety-like behaviors (burrowing and spontaneous wheel running), depressive behavior (forced-swim test), and impairments in fear-conditioning responses alongside reduced hippocampal and cortical BDNF. ${ }^{296-298}$

Offspring derived from mothers fed a high-fat diet show increased anxiety with an increase in BDNF expression in the dorsal hippocampus, suggesting significant developmental effects of a high-fat diet. ${ }^{299}$ In line with the report from Christensen and Christensen on the ratio of saturated to polyunsaturated fats, perinatal and postweaning diets rich in omega-3 polyunsaturated fatty acids have been shown to increase cortical BDNF, TrkB, and nerve growth-factor expression in $\mathrm{C} 57 \mathrm{Bl} / 6$ mice. ${ }^{300}$ This would suggest that while high-fat diets rich in saturated fats may reduce BDNF, altering memory performance, anxiety, and depressive behaviors, foods rich in polyunsaturated fats increase BDNF and may therefore be beneficial to mental health. However, once again there are inconsistencies in the literature, with other reports showing no effect of omega-3 on brain BDNF expression, but increases in serum BDNF in a ketamine-induced rat model of schizophrenia. ${ }^{301}$

Overall, it is evident that a high-fat diet reduces BDNF expression and can affect learning and memory as well as anxiety-like and depressive-like behaviors. What is promising is that the effects of a high-fat diet can be reversed by exercise and other dietary supplements. Below we will discuss a variety of dietary supplements that have been shown to increase BDNF expression and improve mental health.

\section{Dietary flavonoids}

There is a wealth of literature that describes the cognitiveenhancing effects of a group of phytochemicals known as flavonoids. A variety of different flavonoids have been shown to increase hippocampal BDNF and neurogenesis, reduce neurotoxic and neuroinflammatory cell damage/ loss, and increase brain blood flow, making flavonoids prime therapeutic targets for neurodegenerative disorders. ${ }^{302}$ Probably the most consistent finding is the positive effect of flavonoids on BDNF expression. Given the role of BDNF in mental health disorders (described above), more recent studies have explored the use of flavonoids in animal models of psychiatric disorders.

\section{7,8-dihydroxyflavone (7,8-DHF)}

One of the most commonly studied flavonoids is 7,8dihydroxyflavone (7,8-DHF). 7,8-DHF is a naturally occurring flavonoid from the plant Godmania aesculifolia, which binds with a high affinity to the TrkB receptor to initiate dimerization and autophosphorylation. ${ }^{303}$ Following characterization of 7,8-DHF, one of the first behavioral studies reported antidepressant-like effects; with oral administration of 7,8-DHF shown to activate TrkB in the mouse hippocampus and to reduce immobility in the forced-swim test and tail-suspension test. ${ }^{304}$ In addition, deficits in learned fear in neocortical BDNF knockout mice were rescued by a peripheral intraperitoneal injection of 7,8-DHF. ${ }^{305}$ This same group showed beneficial effects of 7,8-DHF on appetitive and aversive memory domains in neocortical BDNF knockout mice. ${ }^{306}$ Another group was able to show that systemic 7,8DHF administration ( $5 \mathrm{mg} / \mathrm{kg}$ administered intraperitoneally) was able to activate TrkB receptors in the amygdala and enhanced fear acquisition and extinction. ${ }^{307}$ 7,8-DHF has therefore been suggested as a potential therapeutic for posttraumatic stress disorder. ${ }^{308}$

Acute 7,8 -DHF in striatal slices potentiated dopamine release. ${ }^{309}$ In addition, treatment with 7,8-DHF improved deficits in prepulse inhibition (a measure of sensorimotor gating) in mice after administration of methamphetamine. ${ }^{310}$ Furthermore, 14 days of 7,8-DHF treatment increased TrkB phosphorylation at multiple sites, promoted hippocampal synaptic plasticity, and rescued spatial working memory in a MK-801-induced animal model of schizophrenia. ${ }^{311}$ Thus there is great potential for the use of 7,8-DHF as an adjunctive treatment for the cognitive and attention impairments associated with schizophrenia.

\section{Other flavonoids}

In a recent study exploring the effects of a range of flavonoids on synthesis and secretion of neurotrophic factors, 33 flavonoids were assessed in cultured rat astrocytes. The isoflavones calycosin and genistein and the flavanol isorhammnetin were particularly strong activators of BDNF expression, ${ }^{312}$ while baicalein had no effect and icariin (a flavonoid from the Chinese medicinal herb Epimedii) produced only mild increases in BDNF. In animal models, baicalein elevated BDNF-phosphorylated cAMP (adenosine $3^{\prime} 5^{\prime}$ cyclic monophosphate)-response element binding protein signaling in the hippocampus and prevented spatial learning and memory deficits following whole brain irradiation in C57Bl/6 mice. ${ }^{313}$ However, others have shown no effect of baicalein on spatial memory in the Morris Water Maze. ${ }^{314}$ Nobiletin (a dietary flavonoid isolated from citrus fruit), as well as blueberry powder (Vaccinium corymbosum) and icariin have all been shown to increase hippocampal BDNF and improve spatial memory in rodents. ${ }^{315-318}$ Soy isoflavone supplementation, including 
daidzein, genistein and glycitin, have also shown beneficial effects on spatial memory in human ${ }^{319}$ and rodent studies, ${ }^{320}$ and this coincided with an increase in hippocampal BDNF expression in the rodent study.

Flavonoids also show antidepressant effects in several animal models. In a rat model of depression induced by chronic unpredictable mild stress, baicalein recovered hippocampal BDNF expression and extracellular-signal-regulated kinase phosphorylation and significantly reduced immobility time in the forced-swim test and tail-suspension test. ${ }^{321}$ Nobiletin, as well as astilbin (a tea extract) and icariin, have also shown antidepressant properties, ${ }^{322-324}$ which were proposed to be regulated by activation of the BDNF signaling pathway. ${ }^{323-325}$ Phytoestrogens such as flaxseed (secoisolariciresinol diglycoside) and Tualang Honey show antidepressant effects, also thought to be regulated via BDNF. ${ }^{326,327}$

\section{Polyphenols}

Interestingly, a recent study analyzing the effects of phenolic acids on spatial memory found that in comparison to alcohol-matched controls, aged rats receiving Champagne wine for 6 weeks showed improved spatial working memory and hippocampal and cortical BDNF protein. ${ }^{328}$ Other polyphenols such as curcumin from turmeric, Epigallocatechin gallate from green tea, and olive polyphenols have also been shown to increase BDNF expression and alleviate depressive symptoms. ${ }^{329,330}$ Theanine (a component of green tea and black tea) has also been shown to increase levels of BDNF and has been suggested as a therapeutic for a wide range of mental health disorders, including schizophrenia and depression. ${ }^{331}$

\section{Conclusion}

Research evidence points to abnormal BDNF signaling being a common and vital participant in the aetiology and pathophysiology of many psychiatric disorders including depression, schizophrenia, and bipolar disorder. To increase BDNF levels in patients is therefore a necessary goal of any treatment. To combat the inefficiency of current treatment methods, more attention should be focused on holistic approaches to achieve this goal, as BDNF is proven to have dynamic responses to environmental influences.

Hippocrates, the father of medicine, has never been more prescient than when he remarked "walking is man's best medicine" and "let food be thy medicine and medicine be thy food." We have reviewed evidence in the literature that suggests that lifestyle alterations such as increased social interaction, mental stimulation, exercise, and a healthy diet including low fat and increased flavonoids and polyphenols can have positive effects in psychiatric diseases via increasing BDNF. This "lifestyle medicine" is already advocated in developed countries for the prevention and treatment of major health issues such as obesity ${ }^{332}$ and should be promoted not as a replacement but as an adjunct and iatrogenic to conventional treatments for psychiatric disorders. Advocating these lifestyle changes can potentially curtail and prevent pathogenesis in those vulnerable to developing psychiatric disorders due to environmental or genetic reasons by maintaining healthy levels of BDNF in the face of adverse circumstances. In patients with reduced BDNF, these regimens can likely complement and enhance pharmacological treatments, resulting in faster, fuller, and longer-lasting recovery of $\mathrm{BDNF}$.

\section{Disclosure}

The authors report no conflicts of interest in this work.

\section{References}

1. Thoenen H. Neurotrophins and activity-dependent plasticity. Prog Brain Res. 2000;128:183-191.

2. Huang EJ, Reichardt LF. Trk receptors: roles in neuronal signal transduction. Annu Rev Biochem. 2003;72:609-642.

3. Götz R, Raulf F, Schartl M. Brain-derived neurotrophic factor is more highly conserved in structure and function than nerve growth factor during vertebrate evolution. J Neurochem. 1992;59(2):432-442.

4. Ernfors P, Lee KF, Jaenisch R. Mice lacking brain-derived neurotrophic factor develop with sensory deficits. Nature. 1994;368(6467): 147-150.

5. Barde YA, Edgar D, Thoenen H. Purification of a new neurotrophic factor from mammalian brain. EMBO J. 1982;1(5):549-553.

6. Lindsay RM, Thoenen H, Barde YA. Placode and neural crest-derived sensory neurons are responsive at early developmental stages to brainderived neurotrophic factor. Dev Biol. 1985;112(2):319-328.

7. Buchman VL, Davies AM. Different neurotrophins are expressed and act in a developmental sequence to promote the survival of embryonic sensory neurons. Development. 1993;118(3):989-1001.

8. Cohen-Cory S, Kidane AH, Shirkey NJ, Marshak S. Brain-derived neurotrophic factor and the development of structural neuronal connectivity. Dev Neurobiol. 2010;70(5):271-288.

9. Wright MA, Ribera AB. Brain-derived neurotrophic factor mediates non-cell-autonomous regulation of sensory neuron position and identity. J Neurosci. 2010;30(43):14513-14521.

10. Lyons WE, Mamounas LA, Ricaurte GA, et al. Brain-derived neurotrophic factor-deficient mice develop aggressiveness and hyperphagia in conjunction with brain serotonergic abnormalities. Proc Natl Acad Sci U S A. 1999;96(26):15239-15244.

11. Bosse KE, Maina FK, Birbeck JA, et al. Aberrant striatal dopamine transmitter dynamics in brain-derived neurotrophic factor-deficient mice. J Neurochem. 2012;120(3):385-395.

12. Bozdagi O, Rich E, Tronel S, et al. The neurotrophin-inducible gene Vgf regulates hippocampal function and behavior through a brain-derived neurotrophic factor-dependent mechanism. J Neurosci. 2008;28(39): 9857-9869.

13. Inagaki T, Begum $\mathrm{T}$, Reza $\mathrm{F}$, et al. Brain-derived neurotrophic factormediated retrograde signaling required for the induction of long-term potentiation at inhibitory synapses of visual cortical pyramidal neurons. Neurosci Res. 2008;61(2):192-200. 
14. Tanaka J, Horiike Y, Matsuzaki M, Miyazaki T, Ellis-Davies GC, Kasai H. Protein synthesis and neurotrophin-dependent structural plasticity of single dendritic spines. Science. 2008;319(5870): $1683-1687$.

15. Katoh-Semba R, Asano T, Ueda H, et al. Riluzole enhances expression of brain-derived neurotrophic factor with consequent proliferation of granule precursor cells in the rat hippocampus. FASEB J. 2002;16(10): $1328-1330$

16. Pencea V, Bingaman KD, Wiegand SJ, Luskin MB. Infusion of brainderived neurotrophic factor into the lateral ventricle of the adult rat leads to new neurons in the parenchyma of the striatum, septum, thalamus, and hypothalamus. J Neurosci. 2001;21(17):6706-6717.

17. Zigova T, Pencea V, Wiegand SJ, Luskin MB. Intraventricular administration of BDNF increases the number of newly generated neurons in the adult olfactory bulb. Mol Cell Neurosci. 1998;11(4): 234-245.

18. Chan JP, Cordeira J, Calderon GA, Iyer LK, Rios M. Depletion of central BDNF in mice impedes terminal differentiation of new granule neurons in the adult hippocampus. Mol Cell Neurosci. 2008;39(3): 372-383.

19. Lee J, Duan W, Mattson MP. Evidence that brain-derived neurotrophic factor is required for basal neurogenesis and mediates, in part, the enhancement of neurogenesis by dietary restriction in the hippocampus of adult mice. J Neurochem. 2002;82(6):1367-1375.

20. Aid T, Kazantseva A, Piirsoo M, Palm K, Timmusk T. Mouse and rat BDNF gene structure and expression revisited. $J$ Neurosci Res. 2007;85(3):525-535.

21. Chiaruttini C, Sonego M, Baj G, Simonato M, Tongiorgi E. BDNF mRNA splice variants display activity-dependent targeting to distinct hippocampal laminae. Mol Cell Neurosci. 2008;37(1):11-19.

22. Tabuchi A. Synaptic plasticity-regulated gene expression: a key event in the long-lasting changes of neuronal function. Biol Pharm Bull. 2008;31(3):327-335.

23. Nagappan G, Lu B. Activity-dependent modulation of the BDNF receptor TrkB: mechanisms and implications. Trends Neurosci. 2005;28(9): 464-471.

24. Patapoutian A, Reichardt LF. Trk receptors: mediators of neurotrophin action. Curr Opin Neurobiol. 2001;11(3):272-280.

25. Woo NH, Teng HK, Siao CJ, et al. Activation of p75NTR by proBDNF facilitates hippocampal long-term depression. Nat Neurosci. 2005;8(8): 1069-1077.

26. Hashimoto K, Shimizu E, Iyo M. Critical role of brain-derived neurotrophic factor in mood disorders. Brain Res Brain Res Rev. 2004;45(2):104-114.

27. Duman RS. Role of neurotrophic factors in the etiology and treatment of mood disorders. Neuromolecular Med. 2004;5(1):11-25.

28. Ikegame T, Bundo M, Murata Y, Kasai K, Kato T, Iwamoto K. DNA methylation of the BDNF gene and its relevance to psychiatric disorders. J Hum Genet. 2013;58(7):434-438.

29. Autry AE, Monteggia LM. Brain-derived neurotrophic factor and neuropsychiatric disorders. Pharmacol Rev. 2012;64(2):238-258.

30. Balaratnasingam S, Janca A. Brain derived neurotrophic factor: a novel neurotrophin involved in psychiatric and neurological disorders. Pharmacol Ther. 2012;134(1):116-124.

31. Boulle F, van den Hove DL, Jakob SB, et al. Epigenetic regulation of the BDNF gene: implications for psychiatric disorders. Mol Psychiatry. 2012;17(6):584-596.

32. Smith MA, Makino S, Kvetnansky R, Post RM. Stress and glucocorticoids affect the expression of brain-derived neurotrophic factor and neurotrophin-3 mRNAs in the hippocampus. $J$ Neurosci. 1995; 15(3 Pt 1):1768-1777.

33. Smith MA, Makino S, Kvetnanský R, Post RM. Effects of stress on neurotrophic factor expression in the rat brain. Ann N Y Acad Sci. 1995;771:234-239.

34. Nowacka M, Obuchowicz E. BDNF and VEGF in the pathogenesis of stress-induced affective diseases: an insight from experimental studies. Pharmacol Rep. 2013;65(3):535-546.
35. Duman RS, Heninger GR, Nestler EJ. A molecular and cellular theory of depression. Arch Gen Psychiatry. 1997;54(7):597-606.

36. Ferrari AJ, Charlson FJ, Norman RE, et al. Burden of depressive disorders by country, sex, age, and year: findings from the global burden of disease study 2010. PLoS Med. 2013;10(11):e1001547.

37. Murray CJ, Lopez AD. Global mortality, disability, and the contribution of risk factors: Global Burden of Disease Study. Lancet. 1997;349(9063):1436-1442.

38. Whiteford HA, Degenhardt L, Rehm J, et al. Global burden of disease attributable to mental and substance use disorders: findings from the Global Burden of Disease Study 2010. Lancet. 2013;382(9904): $1575-1586$.

39. Ferrari AJ, Norman RE, Freedman G, et al. The burden attributable to mental and substance use disorders as risk factors for suicide: findings from the Global Burden of Disease Study 2010. PLoS One. 2014;9(4):e91936.

40. Buckley PF, Miller BJ, Lehrer DS, Castle DJ. Psychiatric comorbidities and schizophrenia. Schizophr Bull. 2009;35(2):383-402.

41. Starkstein SE, Mizrahi R. Depression in Alzheimer's disease. Expert Rev Neurother. 2006;6(6):887-895.

42. Aarsland D, Larsen JP, Lim NG, et al. Range of neuropsychiatric disturbances in patients with Parkinson's disease. J Neurol Neurosurg Psychiatry. 1999;67(4):492-496.

43. Aarsland D, Påhlhagen S, Ballard CG, Ehrt U, Svenningsson P. Depression in Parkinson disease - epidemiology, mechanisms and management. Nat Rev Neurol. 2011;8(1):35-47.

44. Jacob EL, Gatto NM, Thompson A, Bordelon Y, Ritz B. Occurrence of depression and anxiety prior to Parkinson's disease. Parkinsonism Relat Disord. 2010;16(9):576-581.

45. Gargiulo M, Lejeune S, Tanguy ML, et al. Long-term outcome of presymptomatic testing in Huntington disease. Eur J Hum Genet. 2009;17(2):165-171.

46. Shiwach R. Psychopathology in Huntington's disease patients. Acta Psychiatr Scand. 1994;90(4):241-246.

47. Shiwach RS, Norbury CG. A controlled psychiatric study of individuals at risk for Huntington's disease. Br J Psychiatry. 1994;165(4):500-505.

48. Mendenhall E, Norris SA, Shidhaye R, Prabhakaran D. Depression and type 2 diabetes in low- and middle-income countries: a systematic review. Diabetes Res Clin Pract. 2014;103(2):276-285.

49. Charlson FJ, Moran AE, Freedman G, et al. The contribution of major depression to the global burden of ischemic heart disease: a comparative risk assessment. BMC Med. 2013;11:250.

50. Halaris A. Comorbidity between depression and cardiovascular disease. Int Angiol. 2009;28(2):92-99.

51. Halaris A. Inflammation, heart disease, and depression. Curr Psychiatry Rep. 2013;15(10):400.

52. McKeon A, Frye MA, Delanty N. The alcohol withdrawal syndrome. J Neurol Neurosurg Psychiatry. 2008;79(8):854-862.

53. Duman RS, Malberg J, Nakagawa S, D'Sa C. Neuronal plasticity and survival in mood disorders. Biol Psychiatry. 2000;48(8):732-739.

54. Duman RS. Pathophysiology of depression: the concept of synaptic plasticity. Eur Psychiatry. 2002;17 Suppl 3:306-310.

55. Manji HK, Quiroz JA, Sporn J, et al. Enhancing neuronal plasticity and cellular resilience to develop novel, improved therapeutics for difficult-to-treat depression. Biol Psychiatry. 2003;53(8):707-742.

56. Czéh B, Simon M. [Neuroplasticity and depression]. Psychiatr Hung. 2005;20(1):4-17. Hungarian.

57. Cotter DR, Pariante CM, Everall IP. Glial cell abnormalities in major psychiatric disorders: the evidence and implications. Brain Res Bull. 2001;55(5):585-595.

58. Beasley CL, Cotter DR, Everall IP. Density and distribution of white matter neurons in schizophrenia, bipolar disorder and major depressive disorder: no evidence for abnormalities of neuronal migration. Mol Psychiatry. 2002;7(6):564-570.

59. Ongür D, Drevets WC, Price JL. Glial reduction in the subgenual prefrontal cortex in mood disorders. Proc Natl Acad Sci U S A. 1998;95(22):13290-13295. 
60. Rajkowska G. Cell pathology in mood disorders. Semin Clin Neuropsychiatry. 2002;7(4):281-292.

61. Lewin GR, Barde YA. Physiology of the neurotrophins. Annu Rev Neurosci. 1996;19:289-317.

62. McAllister AK. Neurotrophins and neuronal differentiation in the central nervous system. Cell Mol Life Sci. 2001;58(8):1054-1060.

63. McAllister AK, Katz LC, Lo DC. Neurotrophins and synaptic plasticity. Annu Rev Neurosci. 1999;22:295-318.

64. Altar CA. Neurotrophins and depression. Trends Pharmacol Sci. 1999;20(2):59-61.

65. Egan MF, Kojima M, Callicott JH, et al. The BDNF val66met polymorphism affects activity-dependent secretion of BDNF and human memory and hippocampal function. Cell. 2003;112(2):257-269.

66. Chiaruttini C, Vicario A, Li Z, et al. Dendritic trafficking of BDNF mRNA is mediated by translin and blocked by the G196A (Val66Met) mutation. Proc Natl Acad Sci U S A. 2009;106(38): 16481-16486.

67. Kim SN, Kang DH, Yun JY, et al. Impact of the BDNF Val66Met polymorphism on regional brain gray matter volumes: relevance to the stress response. Psychiatry Investig. 2013;10(2):173-179.

68. Hosang GM, Shiles C, Tansey KE, McGuffin P, Uher R. Interaction between stress and the BDNF Val66Met polymorphism in depression: a systematic review and meta-analysis. BMC Med. 2014;12:7.

69. Lee Y, Lim SW, Kim SY, et al. Association between the BDNF Val66Met polymorphism and chronicity of depression. Psychiatry Investig. 2013;10(1):56-61.

70. Pan W, Banks WA, Fasold MB, Bluth J, Kastin AJ. Transport of brain-derived neurotrophic factor across the blood-brain barrier. Neuropharmacology. 1998;37(12):1553-1561.

71. Karege F, Schwald M, Cisse M. Postnatal developmental profile of brain-derived neurotrophic factor in rat brain and platelets. Neurosci Lett. 2002;328(3):261-264.

72. Yoshimura R, Umene-Nakano W, Hoshuyama T, et al. Plasma levels of brain-derived neurotrophic factor and interleukin- 6 in patients with dysthymic disorder: comparison with age- and sex-matched major depressed patients and healthy controls. Hum Psychopharmacol. 2010;25(7-8):566-569.

73. Yoshida T, Ishikawa M, Niitsu T, et al. Decreased serum levels of mature brain-derived neurotrophic factor (BDNF), but not its precursor proBDNF, in patients with major depressive disorder. PLoS One. 2012;7(8):e42676.

74. Bocchio-Chiavetto L, Bagnardi V, Zanardini R, et al. Serum and plasma BDNF levels in major depression: a replication study and meta-analyses. World J Biol Psychiatry. 2010;11(6):763-773.

75. Shimizu E, Hashimoto K, Okamura N, et al. Alterations of serum levels of brain-derived neurotrophic factor (BDNF) in depressed patients with or without antidepressants. Biol Psychiatry. 2003; 54(1):70-75.

76. Karege F, Perret G, Bondolfi G, Schwald M, Bertschy G, Aubry JM. Decreased serum brain-derived neurotrophic factor levels in major depressed patients. Psychiatry Res. 2002;109(2):143-148.

77. Molendijk ML, Bus BA, Spinhoven P, et al. Serum levels of brainderived neurotrophic factor in major depressive disorder: state-trait issues, clinical features and pharmacological treatment. Mol Psychiatry. 2011;16(11):1088-1095.

78. Munno D, Sterpone S, Fania S, et al. Plasma brain derived neurotrophic factor levels and neuropsychological aspects of depressed patients treated with paroxetine. Panminerva Med. 2013;55(4):377-384.

79. Molendijk ML, Spinhoven P, Polak M, Bus BA, Penninx BW, Elzinga BM. Serum BDNF concentrations as peripheral manifestations of depression: evidence from a systematic review and metaanalyses on 179 associations (N=9484). Mol Psychiatry. 2014;19(7): 791-800.

80. Bus BA, Molendijk ML, Penninx BW, et al. Low serum BDNF levels in depressed patients cannot be attributed to individual depressive symptoms or symptom cluster. World J Biol Psychiatry. Epub November 13, 2013.
81. Dwivedi Y, Rizavi HS, Conley RR, Roberts RC, Tamminga CA, Pandey GN. Altered gene expression of brain-derived neurotrophic factor and receptor tyrosine kinase B in postmortem brain of suicide subjects. Arch Gen Psychiatry. 2003;60(8):804-815.

82. Karege F, Vaudan G, Schwald M, Perroud N, La Harpe R. Neurotrophin levels in postmortem brains of suicide victims and the effects of antemortem diagnosis and psychotropic drugs. Brain Res Mol Brain Res. 2005;136(1-2):29-37.

83. Chen B, Dowlatshahi D, MacQueen GM, Wang JF, Young LT. Increased hippocampal BDNF immunoreactivity in subjects treated with antidepressant medication. Biol Psychiatry. 2001;50(4):260-265.

84. Coffey CE, Wilkinson WE, Weiner RD, et al. Quantitative cerebral anatomy in depression. A controlled magnetic resonance imaging study. Arch Gen Psychiatry. 1993;50(1):7-16.

85. FrodlT, ReinholdE, Koutsouleris N, Reiser M, Meisenzahl EM. Interaction of childhood stress with hippocampus and prefrontal cortex volume reduction in major depression. J Psychiatr Res. 2010;44(13):799-807.

86. Sheline YI, Wang PW, Gado MH, Csernansky JG, Vannier MW. Hippocampal atrophy in recurrent major depression. Proc Natl Acad Sci U S A. 1996;93(9):3908-3913.

87. Sheline YI, Sanghavi M, Mintun MA, Gado MH. Depression duration but not age predicts hippocampal volume loss in medically healthy women with recurrent major depression. $J$ Neurosci. 1999;19(12):5034-5043.

88. Axelson DA, Doraiswamy PM, McDonald WM, et al. Hypercortisolemia and hippocampal changes in depression. Psychiatry Res. 1993;47(2): 163-173.

89. Frodl T, Schüle C, Schmitt G, et al. Association of the brain-derived neurotrophic factor Val66Met polymorphism with reduced hippocampal volumes in major depression. Arch Gen Psychiatry. 2007;64(4): 410-416.

90. Huang Y, Coupland NJ, Lebel RM, et al. Structural changes in hippocampal subfields in major depressive disorder: a high-field magnetic resonance imaging study. Biol Psychiatry. 2013;74(1):62-68.

91. Sheline YI, Gado MH, Kraemer HC. Untreated depression and hippocampal volume loss. Am J Psychiatry. 2003;160(8):1516-1518.

92. Smith R, Chen K, Baxter L, Fort C, Lane RD. Antidepressant effects of sertraline associated with volume increases in dorsolateral prefrontal cortex. J Affect Disord. 2013;146(3):414-419.

93. Lacerda AL, Keshavan MS, Hardan AY, et al. Anatomic evaluation of the orbitofrontal cortex in major depressive disorder. Biol Psychiatry. 2004;55(4):353-358.

94. Lavretsky H, Roybal DJ, Ballmaier M, Toga AW, Kumar A. Antidepressant exposure may protect against decrement in frontal gray matter volumes in geriatric depression. J Clin Psychiatry. 2005;66(8):964-967.

95. Eker C, Kitis O, Taneli F, et al. Correlation of serum BDNF levels with hippocampal volumes in first episode, medication-free depressed patients. Eur Arch Psychiatry Clin Neurosci. 2010;260(7):527-533.

96. Lorenzetti V, Allen NB, Fornito A, Yücel M. Structural brain abnormalities in major depressive disorder: a selective review of recent MRI studies. J Affect Disord. 2009;117(1-2):1-17.

97. Chen ZY, Jing D, Bath KG, et al. Genetic variant BDNF (Val66Met) polymorphism alters anxiety-related behavior. Science. 2006;314(5796):140-143.

98. Cirulli F, Francia N, Berry A, Aloe L, Alleva E, Suomi SJ. Early life stress as a risk factor for mental health: role of neurotrophins from rodents to non-human primates. Neurosci Biobehav Rev. 2009;33(4):573-585.

99. Cirulli F, Berry A, Bonsignore LT, et al. Early life influences on emotional reactivity: evidence that social enrichment has greater effects than handling on anxiety-like behaviors, neuroendocrine responses to stress and central BDNF levels. Neurosci Biobehav Rev. 2010;34(6):808-820.

100. Siuciak JA, Lewis DR, Wiegand SJ, Lindsay RM. Antidepressantlike effect of brain-derived neurotrophic factor (BDNF). Pharmacol Biochem Behav. 1997;56(1):131-137.

101. Shirayama Y, Chen AC, Nakagawa S, Russell DS, Duman RS. Brainderived neurotrophic factor produces antidepressant effects in behavioral models of depression. J Neurosci. 2002;22(8):3251-3261. 
102. Branchi I, D’Andrea I, Sietzema J, et al. Early social enrichment augments adult hippocampal BDNF levels and survival of BrdUpositive cells while increasing anxiety- and "depression"-like behavior. J Neurosci Res. 2006;83(6):965-973.

103. MontkowskiA, Holsboer F. Intact spatial learning and memory in transgenic mice with reduced BDNF. Neuroreport. 1997;8(3):779-782.

104. MacQueen GM, Ramakrishnan K, Croll SD, et al. Performance of heterozygous brain-derived neurotrophic factor knockout mice on behavioral analogues of anxiety, nociception, and depression. Behav Neurosci. 2001;115(5):1145-1153.

105. Gorski JA, Balogh SA, Wehner JM, Jones KR. Learning deficits in forebrain-restricted brain-derived neurotrophic factor mutant mice. Neuroscience. 2003;121(2):341-354.

106. Saarelainen T, Hendolin P, Lucas G, et al. Activation of the TrkB neurotrophin receptor is induced by antidepressant drugs and is required for antidepressant-induced behavioral effects. J Neurosci. 2003;23(1):349-357.

107. Rosenblat JD, Cha DS, Mansur RB, McIntyre RS. Inflamed moods: A review of the interactions between inflammation and mood disorders. Prog Neuropsychopharmacol Biol Psychiatry. 2014;53:23-34.

108. Ratnayake U, Quinn T, Walker DW, Dickinson H. Cytokines and the neurodevelopmental basis of mental illness. Front Neurosci. 2013;7:180.

109. Dowlati Y, Herrmann N, Swardfager W, et al. A meta-analysis of cytokines in major depression. Biol Psychiatry. 2010;67(5):446-457.

110. Liu Y, Ho RC, Mak A. Interleukin (IL)-6, tumour necrosis factor alpha (TNF-alpha) and soluble interleukin-2 receptors (sIL-2R) are elevated in patients with major depressive disorder: a meta-analysis and meta-regression. J Affect Disord. 2012;139(3):230-239.

111. Anisman H, Hayley S, Turrin N, Merali Z. Cytokines as a stressor: implications for depressive illness. Int $J$ Neuropsychopharmacol. 2002;5(4):357-373.

112. Maier SF, Watkins LR. Cytokines for psychologists: implications of bidirectional immune-to-brain communication for understanding behavior, mood, and cognition. Psychol Rev. 1998;105(1):83-107.

113. Churchill L, Taishi P, Wang M, et al. Brain distribution of cytokine mRNA induced by systemic administration of interleukin-1beta or tumor necrosis factor alpha. Brain Res. 2006;1120(1):64-73.

114. Kenis G, Prickaerts J, van Os J, et al. Depressive symptoms following interferon- $\alpha$ therapy: mediated by immune-induced reductions in brain-derived neurotrophic factor? Int J Neuropsychopharmacol. 2011;14(2):247-253.

115. Lotrich FE, Albusaysi S, Ferrell RE. Brain-derived neurotrophic factor serum levels and genotype: association with depression during interferon-alpha treatment. Neuropsychopharmacology. 2013;38(6): 985-995.

116. Guan Z, Fang J. Peripheral immune activation by lipopolysaccharide decreases neurotrophins in the cortex and hippocampus in rats. Brain Behav Immun. 2006;20(1):64-71.

117. Tong L, Balazs R, Soiampornkul R, Thangnipon W, Cotman CW. Interleukin-1 beta impairs brain derived neurotrophic factor-induced signal transduction. Neurobiol Aging. 2008;29(9):1380-1393.

118. Rage F, Silhol M, Tapia-Arancibia L. IL-1beta regulation of BDNF expression in rat cultured hypothalamic neurons depends on the presence of glial cells. Neurochem Int. 2006;49(5):433-441.

119. Cortese GP, Barrientos RM, Maier SF, Patterson SL. Aging and a peripheral immune challenge interact to reduce mature brain-derived neurotrophic factor and activation of TrkB, PLCgamma1, and ERK in hippocampal synaptoneurosomes. J Neurosci. 2011;31(11): 4274-4279.

120. Peng $\mathrm{CH}$, Chiou SH, Chen SJ, et al. Neuroprotection by imipramine against lipopolysaccharide-induced apoptosis in hippocampus-derived neural stem cells mediated by activation of BDNF and the MAPK pathway. Eur Neuropsychopharmacol. 2008;18(2):128-140.

121. Angelucci F, Brenè S, Mathé AA. BDNF in schizophrenia, depression and corresponding animal models. Mol Psychiatry. 2005;10(4): $345-352$.
122. Thompson Ray M, Weickert CS, Wyatt E, Webster MJ. Decreased BDNF, trkB-TK+ and GAD67 mRNA expression in the hippocampus of individuals with schizophrenia and mood disorders. J Psychiatry Neurosci. 2011;36(3):195-203.

123. Weickert CS, Hyde TM, Lipska BK, Herman MM, Weinberger DR, Kleinman JE. Reduced brain-derived neurotrophic factor in prefrontal cortex of patients with schizophrenia. Mol Psychiatry. 2003;8(6): 592-610.

124. Weickert CS, Ligons DL, Romanczyk T, et al. Reductions in neurotrophin receptor mRNAs in the prefrontal cortex of patients with schizophrenia. Mol Psychiatry. 2005;10(7):637-650.

125. Durany N, Michel T, Zöchling R, et al. Brain-derived neurotrophic factor and neurotrophin 3 in schizophrenic psychoses. Schizophr Res. 2001;52(1-2):79-86.

126. Iritani S, Niizato K, Nawa H, Ikeda K, Emson PC. Immunohistochemical study of brain-derived neurotrophic factor and its receptor, TrkB, in the hippocampal formation of schizophrenic brains. Prog Neuropsychopharmacol Biol Psychiatry. 2003;27(5):801-807.

127. Takahashi M, Shirakawa O, Toyooka K, et al. Abnormal expression of brain-derived neurotrophic factor and its receptor in the corticolimbic system of schizophrenic patients. Mol Psychiatry. 2000;5(3): 293-300.

128. Grillo RW, Ottoni GL, Leke R, Souza DO, Portela LV, Lara DR. Reduced serum BDNF levels in schizophrenic patients on clozapine or typical antipsychotics. J Psychiatr Res. 2007;41(1-2):31-35.

129. Ikeda Y, Yahata N, Ito I, Nagano M, et al. Low serum levels of brainderived neurotrophic factor and epidermal growth factor in patients with chronic schizophrenia. Schizophr Res. 2008;101(1-3):58-66.

130. Tan YL, Zhou DF, Cao LY, Zou YZ, Zhang XY. Decreased BDNF in serum of patients with chronic schizophrenia on long-term treatment with antipsychotics. Neurosci Lett. 2005;382(1-2):27-32.

131. Toyooka K, Asama K, Watanabe Y, et al. Decreased levels of brainderived neurotrophic factor in serum of chronic schizophrenic patients. Psychiatry Res. 2002;110(3):249-257.

132. Xiu MH, Hui L, Dang YF, et al. Decreased serum BDNF levels in chronic institutionalized schizophrenia on long-term treatment with typical and atypical antipsychotics. Prog Neuropsychopharmacol Biol Psychiatry. 2009;33(8):1508-1512.

133. Chen da C1, Wang J, Wang B, et al. Decreased levels of serum brainderived neurotrophic factor in drug-naive first-episode schizophrenia: relationship to clinical phenotypes. Psychopharmacology (Berl). 2009;207(3):375-380.

134. Palomino A, Vallejo-Illarramendi A, González-Pinto A, et al. Decreased levels of plasma BDNF in first-episode schizophrenia and bipolar disorder patients. Schizophr Res. 2006;86(1-3):321-322.

135. Rizos EN, Rontos I, Laskos E, et al. Investigation of serum BDNF levels in drug-naive patients with schizophrenia. Prog Neuropsychopharmacol Biol Psychiatry. 2008;32(5):1308-1311.

136. Reis HJ, Nicolato R, Barbosa IG, Teixeira do Prado PH, RomanoSilva MA, Teixeira AL. Increased serum levels of brain-derived neurotrophic factor in chronic institutionalized patients with schizophrenia. Neurosci Lett. 2008;439(2):157-159.

137. Huang TL, Lee CT. Associations between serum brain-derived neurotrophic factor levels and clinical phenotypes in schizophrenia patients. J Psychiatr Res. 2006;40(7):664-668.

138. Shimizu E, Hashimoto K, Watanabe H, et al. Serum brain-derived neurotrophic factor (BDNF) levels in schizophrenia are indistinguishable from controls. Neurosci Lett. 2003;351(2):111-114.

139. Komulainen P, Pedersen M, Hänninen T, et al. BDNF is a novel marker of cognitive function in ageing women: the DR's EXTRA Study. Neurobiol Learn Mem. 2008;90(4):596-603.

140. Green MJ, Matheson SL, Shepherd A, Weickert CS, Carr VJ. Brainderived neurotrophic factor levels in schizophrenia: a systematic review with meta-analysis. Mol Psychiatry. 2011;16(9):960-972.

141. Guillin O, Diaz J, Carroll P, Griffon N, Schwartz JC, Sokoloff P. BDNF controls dopamine D3 receptor expression and triggers behavioural sensitization. Nature. 2001;411(6833):86-89. 
142. Hasbi A, Fan T, Alijaniaram M, et al. Calcium signaling cascade links dopamine D1-D2 receptor heteromer to striatal BDNF production and neuronal growth. Proc Natl Acad Sci U S A. 2009;106(50): 21377-21382.

143. Nandra KS, Agius M. The differences between typical and atypical antipsychotics: the effects on neurogenesis. Psychiatr Danub. 2012; 24 Suppl 1:S95-S99.

144. Yoshimura R, Hori H, Ikenouchi-Sugita A, et al. Aripiprazole altered plasma levels of brain-derived neurotrophic factor and catecholamine metabolites in first-episode untreated Japanese schizophrenia patients. Hum Psychopharmacol. 2012;27(1):33-38.

145. Pedrini M, Chendo I, Grande I, et al. Serum brain-derived neurotrophic factor and clozapine daily dose in patients with schizophrenia: a positive correlation. Neurosci Lett. 2011;491(3):207-210.

146. Huang TL. Effects of antipsychotics on the BDNF in schizophrenia. Curr Med Chem. 2013;20(3):345-350.

147. Lee JG, Cho HY, Park SW, Seo MK, Kim YH. Effects of olanzapine on brain-derived neurotrophic factor gene promoter activity in SH-SY5Y neuroblastoma cells. Prog Neuropsychopharmacol Biol Psychiatry. 2010;34(6):1001-1006.

148. Fumagalli F, Calabrese F, Luoni A, Bolis F, Racagni G, Riva MA. Modulation of BDNF expression by repeated treatment with the novel antipsychotic lurasidone under basal condition and in response to acute stress. Int J Neuropsychopharmacol. 2012;15(2):235-346.

149. Chao HM, Kao HT, Porton B. BDNF Val66Met variant and age of onset in schizophrenia. Am J Med Genet B Neuropsychiatr Genet. 2008;147B(4):505-506.

150. Hong CJ, Yu YW, Lin CH, Tsai SJ. An association study of a brainderived neurotrophic factor Val66Met polymorphism and clozapine response of schizophrenic patients. Neurosci Lett. 2003;349(3): 206-208.

151. Nikolac Perkovic M, Nedic Erjavec G, Zivkovic M, et al. Association between the brain-derived neurotrophic factor Val66Met polymorphism and therapeutic response to olanzapine in schizophrenia patients. Psychopharmacology (Berl). Epub March 5, 2014.

152. Zhang JP, Lencz T, Geisler S, DeRosse P, Bromet EJ, Malhotra AK Genetic variation in BDNF is associated with antipsychotic treatment resistance in patients with schizophrenia. Schizophr Res. 2013;146(1-3):285-288.

153. Buckley PF, Pillai A, Howell KR. Brain-derived neurotrophic factor: findings in schizophrenia. Curr Opin Psychiatry. 2011;24(2): $122-127$.

154. Rybakowski JK. BDNF gene: functional Val66Met polymorphism in mood disorders and schizophrenia. Pharmacogenomics. 2008;9(11): 1589-1593.

155. Ho BC, Milev P, O’Leary DS, Librant A, Andreasen NC, Wassink TH. Cognitive and magnetic resonance imaging brain morphometric correlates of brain-derived neurotrophic factor Val66Met gene polymorphism in patients with schizophrenia and healthy volunteers. Arch Gen Psychiatry. 2006;63(7):731-740.

156. Mandelman SD, Grigorenko EL. BDNF Val66Met and cognition: all, none, or some? A meta-analysis of the genetic association. Genes Brain Behav. 2012;11(2):127-136.

157. Aas M, Haukvik UK, Djurovic S, et al. BDNF val66met modulates the association between childhood trauma, cognitive and brain abnormalities in psychoses. Prog Neuropsychopharmacol Biol Psychiatry. 2013;46:181-188.

158. Klug M, Hill RA, Choy KH, Kyrios M, Hannan AJ, van den Buuse M. Long-term behavioral and NMDA receptor effects of young-adult corticosterone treatment in BDNF heterozygous mice. Neurobiol Dis. 2012;46(3):722-731.

159. Heldt SA, Stanek L, Chhatwal JP, Ressler KJ. Hippocampus-specific deletion of BDNF in adult mice impairs spatial memory and extinction of aversive memories. Mol Psychiatry. 2007;12(7):656-670.

160. Monteggia LM, Luikart B, Barrot M, et al. Brain-derived neurotrophic factor conditional knockouts show gender differences in depressionrelated behaviors. Biol Psychiatry. 2007;61(2):187-197.
161. Guo C, Yang Y, Su Y, Si T. Postnatal BDNF expression profiles in prefrontal cortex and hippocampus of a rat schizophrenia model induced by MK-801 administration. J Biomed Biotechnol. 2010;2010:783297.

162. Liu F, Zou X, Sadovova N, et al. Changes in gene expression after phencyclidine administration in developing rats: a potential animal model for schizophrenia. Int J Dev Neurosci. 2011;29(3):351-358.

163. Kaminitz A, Barzilay R, Segal H, et al. Dominant negative DISC1 mutant mice display specific social behaviour deficits and aberration in BDNF and cannabinoid receptor expression. World J Biol Psychiatry. 2014;15(1):76-82.

164. Hill RA, Wu YW, Gogos A, van den Buuse M. Sex-dependent alterations in BDNF-TrkB signaling in the hippocampus of reelin heterozygous mice: a role for sex steroid hormones. J Neurochem. 2013;126(3):389-399.

165. Gibney SM, McGuinness B, Prendergast C, Harkin A, Connor TJ. $\mathrm{I}$ :C-induced activation of the immune response is accompanied by depression and anxiety-like behaviours, kynurenine pathway activation and reduced BDNF expression. Brain Behav Immun. 2013;28:170-181.

166. Nawa H, Takahashi M, Patterson PH. Cytokine and growth factor involvement in schizophrenia - support for the developmental model. Mol Psychiatry. 2000;5(6):594-603.

167. Miller BJ, Buckley P, Seabolt W, Mellor A, Kirkpatrick B. Metaanalysis of cytokine alterations in schizophrenia: clinical status and antipsychotic effects. Biol Psychiatry. 2011;70(7):663-671.

168. Mondelli V, Cattaneo A, Belvederi Murri M, et al. Stress and inflammation reduce brain-derived neurotrophic factor expression in first-episode psychosis: a pathway to smaller hippocampal volume. J Clin Psychiatry. 2011;72(12):1677-1684.

169. Kessler RC, Berglund P, Demler O, Jin R, Merikangas KR, Walters EE. Lifetime prevalence and age-of-onset distributions of DSM-IV disorders in the National Comorbidity Survey Replication. Arch Gen Psychiatry. 2005;62(6):593-602.

170. Smoller JW, Finn CT. Family, twin, and adoption studies of bipolar disorder. Am J Med Genet C Semin Med Genet. 2003;123C(1):48-58.

171. Maier W, Lichtermann D, Minges J, et al. Continuity and discontinuity of affective disorders and schizophrenia. Results of a controlled family study. Arch Gen Psychiatry. 1993;50(11):871-883.

172. Fan J, Sklar P. Genetics of bipolar disorder: focus on BDNF Val66Met polymorphism. Novartis Found Symp. 2008;289:60-72; discussion 72-73, 87-93.

173. Rabie MA, Mohsen M, Ibrahim M, El-Sawy Mahmoud R. Serum level of brain derived neurotrophic factor (BDNF) among patients with bipolar disorder. J Affect Disord. 2014;162:67-72.

174. Fernandes BS, Gama CS, Ceresér KM, et al. Brain-derived neurotrophic factor as a state-marker of mood episodes in bipolar disorders: a systematic review and meta-regression analysis. J Psychiatr Res. 2011;45(8):995-1004.

175. Li Z, Zhang C, Fan J, et al. Brain-derived neurotrophic factor levels and bipolar disorder in patients in their first depressive episode: 3-year prospective longitudinal study. Br J Psychiatry. 2014;205(1):29-35.

176. Kenna HA, Reynolds-May M, Stepanenko A, Ketter TA, Hallmayer J, Rasgon NL. Blood levels of brain derived neurotrophic factor in women with bipolar disorder and healthy control women. $J$ Affect Disord. 2014;156:214-218.

177. Barbosa IG, Rocha NP, Miranda AS, et al. Increased BDNF levels in long-term bipolar disorder patients. Rev Bras Psiquiatr. 2013;35(1): 67-69.

178. Grande I, Kapczinski F, Stertz L, et al. Peripheral brain-derived neurotrophic factor changes along treatment with extended release quetiapine during acute mood episodes: an open-label trial in drug-free patients with bipolar disorder. J Psychiatr Res. 2012;46(11):1511-1514.

179. Ray MT, Shannon Weickert C, Webster MJ. Decreased BDNF and TrkB mRNA expression in multiple cortical areas of patients with schizophrenia and mood disorders. Transl Psychiatry. 2014;4:e389.

180. Dunham JS, Deakin JF, Miyajima F, Payton A, Toro CT. Expression of hippocampal brain-derived neurotrophic factor and its receptors in Stanley consortium brains. J Psychiatr Res. 2009;43(14):1175-1184. 
181. Teh CA, Lee TS, Kuchibhatla M, et al. Bipolar disorder, brain-derived neurotrophic factor (BDNF) Val66Met polymorphism and brain morphology. PLoS One. 2012;7(7):e38469.

182. Brietzke E, Stertz L, Fernandes BS, et al. Comparison of cytokine levels in depressed, manic and euthymic patients with bipolar disorder. J Affect Disord. 2009;116(3):214-217.

183. Kauer-Sant'Anna M, Kapczinski F, Andreazza AC, et al. Brainderived neurotrophic factor and inflammatory markers in patients with early- vs late-stage bipolar disorder. Int J Neuropsychopharmacol. 2009;12(4):447-458.

184. Goldstein BI, Collinger KA, Lotrich F, et al. Preliminary findings regarding proinflammatory markers and brain-derived neurotrophic factor among adolescents with bipolar spectrum disorders. J Child Adolesc Psychopharmacol. 2011;21(5):479-484.

185. Homberg JR, Molteni R, Calabrese F, Riva MA. The serotoninBDNF duo: Developmental implications for the vulnerability to psychopathology. Neurosci Biobehav Rev. 2014;43C:35-47.

186. Hill RA, Murray SS, Halley PG, Binder MD, Martin SJ, van den Buuse M. Brain-derived neurotrophic factor expression is increased in the hippocampus of 5-HT(2C) receptor knockout mice. Hippocampus. 2011;21(4):434-445.

187. Wu YC, Hill RA, Klug M, van den Buuse M. Sex-specific and regionspecific changes in BDNF-TrkB signalling in the hippocampus of 5-HT1A receptor and BDNF single and double mutant mice. Brain Res. 2012;1452:10-17.

188. Duman RS, Monteggia LM. A neurotrophic model for stress-related mood disorders. Biol Psychiatry. 2006;59(12):1116-1127.

189. Allaman I, Fiumelli H, Magistretti PJ, Martin JL. Fluoxetine regulates the expression of neurotrophic/growth factors and glucose metabolism in astrocytes. Psychopharmacology (Berl). 2011;216(1):75-84.

190. Gervasoni N, Aubry JM, Bondolfi G, et al. Partial normalization of serum brain-derived neurotrophic factor in remitted patients after a major depressive episode. Neuropsychobiology. 2005;51(4):234-238.

191. Nibuya M, Nestler EJ, Duman RS. Chronic antidepressant administration increases the expression of cAMP response element binding protein (CREB) in rat hippocampus. $J$ Neurosci. 1996;16(7):2365-2372.

192. Nibuya M, Morinobu S, Duman RS. Regulation of BDNF and trkB mRNA in rat brain by chronic electroconvulsive seizure and antidepressant drug treatments. J Neurosci. 1995;15(11):7539-7547.

193. Monteggia LM, Barrot M, Powell CM, et al. Essential role of brainderived neurotrophic factor in adult hippocampal function. Proc Natl Acad Sci U S A. 2004;101(29):10827-10832.

194. Koponen E, Rantamäki T, Voikar V, Saarelainen T, MacDonald E, Castrén E. Enhanced BDNF signaling is associated with an antidepressant-like behavioral response and changes in brain monoamines. Cell Mol Neurobiol. 2005;25(6):973-980.

195. Liu X, Chan CB, Qi Q, et al. Optimization of a small tropomyosinrelated kinase $\mathrm{B}$ (TrkB) agonist 7,8-dihydroxyflavone active in mouse models of depression. J Med Chem. 2012;55(19):8524-8537.

196. Kozisek ME, Middlemas D, Bylund DB. Brain-derived neurotrophic factor and its receptor tropomyosin-related kinase B in the mechanism of action of antidepressant therapies. Pharmacol Ther. 2008;117(1):30-51.

197. Pittenger C, Duman RS. Stress, depression, and neuroplasticity: a convergence of mechanisms. Neuropsychopharmacology. 2008;33(1):88-109.

198. Martinowich K, Manji H, Lu B. New insights into BDNF function in depression and anxiety. Nat Neurosci. 2007;10(9):1089-1093.

199. Groves JO. Is it time to reassess the BDNF hypothesis of depression? Mol Psychiatry. 2007;12(12):1079-1088.

200. Sairanen M, Lucas G, Ernfors P, Castrén M, Castrén E. Brain-derived neurotrophic factor and antidepressant drugs have different but coordinated effects on neuronal turnover, proliferation, and survival in the adult dentate gyrus. J Neurosci. 2005;25(5):1089-1094.

201. Nestler EJ, Barrot M, DiLeone RJ, Eisch AJ, Gold SJ, Monteggia LM. Neurobiology of depression. Neuron. 2002;34(1):13-25.
202. Katsuki A, Yoshimura R, Kishi T, et al. Serum levels of brain-derived neurotrophic factor (BDNF), BDNF gene Val66Met polymorphism, or plasma catecholamine metabolites, and response to mirtazapine in Japanese patients with major depressive disorder (MDD). CNS Spectr. 2012;17(3):155-163.

203. Schmidt HD, Duman RS. Peripheral BDNF produces antidepressant-like effects in cellular and behavioral models. Neuropsychopharmacology. 2010;35(12):2378-2391.

204. Pearse RN, Swendeman SL, Li Y, Rafii D, Hempstead BL. A neurotrophin axis in myeloma: TrkB and BDNF promote tumor-cell survival. Blood. 2005;105(11):4429-4436.

205. Adessi C, Soto C. Converting a peptide into a drug: strategies to improve stability and bioavailability. Curr Med Chem. 2002;9(9):963-978.

206. Egleton RD, Davis TP. Development of neuropeptide drugs that cross the blood-brain barrier. NeuroRx. 2005;2(1):44-53.

207. Brown RE. The life and work of Donald Olding Hebb. Acta Neurol Taiwan. 2006;15(2):127-142.

208. van Praag H, Kempermann G, Gage FH. Neural consequences of environmental enrichment. Nat Rev Neurosci. 2000;1(3):191-198.

209. Nithianantharajah J, Hannan AJ. Enriched environments, experiencedependent plasticity and disorders of the nervous system. Nat Rev Neurosci. 2006;7(9):697-709.

210. Rosenzweig MR, Krech D, Bennett EL, Diamond MC. Effects of environmental complexity and training on brain chemistry and anatomy: a replication and extension. J Comp Physiol Psychol. 1962;55:429-437.

211. Altman J, Das GD, Autoradiographic examination of the effects of enriched environment on the rate of glial multiplication in the adult rat brain. Nature. 1964;204:1161-1163.

212. Diamond MC, Krech D, Rosenzweig MR. The effects of an enriched environment on the histology of the rat cerebral cortex. J Comp Neurol. 1964;123:111-120.

213. Ma XC, Jiang D, Jiang WH, et al. Social isolation-induced aggression potentiates anxiety and depressive-like behavior in male mice subjected to unpredictable chronic mild stress. PLoS One. 2011;6(6):e20955.

214. Martin AL, Brown RE. The lonely mouse: verification of a separationinduced model of depression in female mice. Behav Brain Res. 2010;207(1):196-207.

215. Brenes Sáenz JC, Villagra OR, Fornaguera Trías J. Factor analysis of Forced Swimming test, Sucrose Preference test and Open Field test on enriched, social and isolated reared rats. Behav Brain Res. 2006;169(1): 57-65.

216. Koh S, Magid R, Chung H, Stine CD, Wilson DN. Depressive behavior and selective down-regulation of serotonin receptor expression after early-life seizures: reversal by environmental enrichment. Epilepsy Behav. 2007;10(1):26-31.

217. Richter SH, Zeuch B, Riva MA, Gass P, Vollmayr B. Environmental enrichment ameliorates depressive-like symptoms in young rats bred for learned helplessness. Behav Brain Res. 2013;252:287-292.

218. Hendriksen H, Meulendijks D, Douma TN, et al. Environmental enrichment has antidepressant-like action without improving learning and memory deficits in olfactory bulbectomized rats. Neuropharmacology. 2012;62(1):270-277.

219. Pang TY, Du X, Catchlove WA, Renoir T, Lawrence AJ, Hannan AJ. Positive environmental modification of depressive phenotype and abnormal hypothalamic-pituitary-adrenal axis activity in female C57BL/6J mice during abstinence from chronic ethanol consumption. Front Pharmacol. 2013;4:93.

220. Pang TY, Du X, Zajac MS, Howard ML, Hannan AJ. Altered serotonin receptor expression is associated with depression-related behavior in the R6/1 transgenic mouse model of Huntington's disease. Hum Mol Genet. 2009;18(4):753-766.

221. Tanti A, Westphal WP, Girault V, et al. Region-dependent and stage-specific effects of stress, environmental enrichment, and antidepressant treatment on hippocampal neurogenesis. Hippocampus. 2013;23(9):797-811. 
222. Schloesser RJ, Lehmann M, Martinowich K, Manji HK, Herkenham M. Environmental enrichment requires adult neurogenesis to facilitate the recovery from psychosocial stress. Mol Psychiatry. 2010;15(12): 1152-1163.

223. Rossi C, Angelucci A, Costantin L, et al. Brain-derived neurotrophic factor (BDNF) is required for the enhancement of hippocampal neurogenesis following environmental enrichment. Eur J Neurosci. 2006;24(7):1850-1856.

224. Ravenelle R, Santolucito HB, Byrnes EM, Byrnes JJ, Donaldson ST. Housing environment modulates physiological and behavioral responses to anxiogenic stimuli in trait anxiety male rats. Neuroscience. 2014;270:76-87.

225. Chourbaji S, Brandwein C, Vogt MA, Dormann C, Hellweg R, Gass P. Nature vs nurture: can enrichment rescue the behavioural phenotype of BDNF heterozygous mice? Behav Brain Res. 2008;192(2):254-258.

226. Chourbaji S, Hörtnagl H, Molteni R, Riva MA, Gass P, Hellweg R. The impact of environmental enrichment on sex-specific neurochemical circuitries - effects on brain-derived neurotrophic factor and the serotonergic system. Neuroscience. 2012;220:267-276.

227. Kidd BL, Urban LA. Mechanisms of inflammatory pain. Br JAnaesth 2001;87(1):3-11.

228. Singhal G, Jaehne EJ, Corrigan F, Baune BT. Cellular and molecular mechanisms of immunomodulation in the brain through environmental enrichment. Front Cell Neuroscil. 2014;8:97.

229. Cruwys T, Dingle GA, Haslam C, Haslam SA, Jetten J, Morton TA Social group memberships protect against future depression, alleviate depression symptoms and prevent depression relapse. Soc Sci Med. 2013;98:179-186.

230. Terzian E, Tognoni G, Bracco R, et al; SIRS (Studio di Intervento sulla Rete Sociale [Social Network Intervention Study]) Collaborative Study Group. Social network intervention in patients with schizophrenia and marked social withdrawal: a randomized controlled study. Can J Psychiatry. 2013;58(11):622-631.

231. Kinser PA, Bourguignon C, Taylor AG, Steeves R. "A feeling of connectedness": perspectives on a gentle yoga intervention for women with major depression. Issues Ment Health Nurs. 2013;34(6):402-411.

232. Pinniger R, Brown RF, Thorsteinsson EB, McKinley P. Argentine tango dance compared with mindfulness meditation and a waiting-list control: a randomised trial for treating depression. Complement Ther Med. 2012;20(6):377-384.

233. Field T, Diego M, Hernandez-Reif M, Medina L, Delgado J, Hernandez A. Yoga and massage therapy reduce prenatal depression and prematurity. J Bodyw Mov Ther. 2012;16(2):204-209.

234. Hou WH, Chiang PT, Hsu TY, Chiu SY, Yen YC. Treatment effects of massage therapy in depressed people: a meta-analysis. $J$ Clin Psychiatry. 2010;71(7):894-901.

235. Cramer H, Lauche R, Klose P, Langhorst J, Dobos G. Yoga for schizophrenia: a systematic review and meta-analysis. $B M C$ Psychiatry. 2013;13:32.

236. Erkkilä J, Punkanen M, Fachner J. Individual music therapy for depression: randomised controlled trial. Br J Psychiatry. 2011;199(2): 132-139.

237. Fachner J, Gold C, Erkkilä J. Music therapy modulates fronto-temporal activity in rest-EEG in depressed clients. Brain Topogr. 2013;26(2) 338-354.

238. Chan MF, Wong ZY, Thayala NV. The effectiveness of music listening in reducing depressive symptoms in adults: a systematic review. Complement Ther Med. 2011;19(6):332-348.

239. Mössler K, Chen X, Heldal TO, Gold C. Music therapy for people with schizophrenia and schizophrenia-like disorders. Cochrane Database Syst Rev. 2011;(12):CD004025.

240. Li WJ, Yu H, Yang JM, et al. Anxiolytic effect of music exposure on BDNFMet/Met transgenic mice. Brain Res. 2010;1347:71-79.

241. Angelucci F, Ricci E, Padua L, Sabino A, Tonali PA. Music exposure differentially alters the levels of brain-derived neurotrophic factor and nerve growth factor in the mouse hypothalamus. Neurosci Lett. 2007;429(2-3):152-155.
242. Angelucci F, Fiore M, Ricci E, Padua L, Sabino A, Tonali PA. Investigating the neurobiology of music: brain-derived neurotrophic factor modulation in the hippocampus of young adult mice. Behav Pharmacol. 2007;18(5-6):491-496.

243. Boso M, Politi P, Barale F, Enzo E. Neurophysiology and neurobiology of the musical experience. Funct Neurol. 2006;21(4):187-191.

244. Driessen E, Hollon SD. Cognitive behavioral therapy for mood disorders: efficacy, moderators and mediators. Psychiatr Clin North Am. 2010;33(3):537-555.

245. Rathod S, Phiri P, Kingdon D. Cognitive behavioral therapy for schizophrenia. Psychiatr Clin North Am. 2010;33(3):527-536.

246. Lynch D, Laws KR, McKenna PJ. Cognitive behavioural therapy for major psychiatric disorder: does it really work? A meta-analytical review of well-controlled trials. Psychol Med. 2010;40(1):9-24.

247. Kobilo T, Liu QR, Gandhi K, Mughal M, Shaham Y, van Praag H. Running is the neurogenic and neurotrophic stimulus in environmental enrichment. Learn Mem. 2011;18(9):605-609.

248. Grégoire CA, Bonenfant D, Le Nguyen A, Aumont A, Fernandes KJ. Untangling the influences of voluntary running, environmental complexity, social housing and stress on adult hippocampal neurogenesis. PLoS One. 2014;9(1):e86237.

249. Kerse N, Hayman KJ, Moyes SA, et al. Home-based activity program for older people with depressive symptoms: DeLLITE - a randomized controlled trial. Ann Fam Med. 2010;8(3):214-223.

250. Lampinen P, Heikkinen E. Reduced mobility and physical activity as predictors of depressive symptoms among community-dwelling older adults: an eight-year follow-up study. Aging Clin Exp Res. 2003;15(3):205-211.

251. Vankova H, Holmerova I, Machacova K, Volicer L, Veleta P, Celko AM. The effect of dance on depressive symptoms in nursing home residents. J Am Med Dir Assoc. Epub June 6, 2014.

252. Suija K, Timonen M, Suviola M, Jokelainen J, Järvelin MR, Tammelin T. The association between physical fitness and depressive symptoms among young adults: results of the Northern Finland 1966 birth cohort study. BMC Public Health. 2013;13:535.

253. McKercher C, Patton GC, Schmidt MD, Venn AJ, Dwyer T, Sanderson K. Physical activity and depression symptom profiles in young men and women with major depression. Psychosom Med. 2013;75(4):366-374.

254. Blumenthal JA, Babyak MA, Doraiswamy PM, et al. Exercise and pharmacotherapy in the treatment of major depressive disorder. Psychosom Med. 2007;69(7):587-596.

255. Russo-Neustadt AA, Alejandre H, Garcia C, Ivy AS, Chen MJ. Hippocampal brain-derived neurotrophic factor expression following treatment with reboxetine, citalopram, and physical exercise. Neuropsychopharmacology. 2004;29(12):2189-2199.

256. Scheewe TW, Backx FJ, Takken T, et al. Exercise therapy improves mental and physical health in schizophrenia: a randomised controlled trial. Acta Psychiatr Scand. 2013;127(6):464-473.

257. Behere RV, Arasappa R, Jagannathan A, et al. Effect of yoga therapy on facial emotion recognition deficits, symptoms and functioning in patients with schizophrenia. Acta Psychiatr Scand. 2011;123(2): 147-153.

258. Vancampfort D, De Hert M, Knapen J, et al. State anxiety, psychological stress and positive well-being responses to yoga and aerobic exercise in people with schizophrenia: a pilot study. Disabil Rehabil. 2011;33(8):684-689.

259. Pajonk FG, Wobrock T, Gruber O, et al. Hippocampal plasticity in response to exercise in schizophrenia. Arch Gen Psychiatry. 2010;67(2):133-143.

260. Kuo FC, Lee CH, Hsieh CH, Kuo P, Chen YC, Hung YJ. Lifestyle modification and behavior therapy effectively reduce body weight and increase serum level of brain-derived neurotrophic factor in obese non-diabetic patients with schizophrenia. Psychiatry Res. 2013;209(2):150-154.

261. Sylvia LG, Friedman ES, Kocsis JH, et al. Association of exercise with quality of life and mood symptoms in a comparative effectiveness study of bipolar disorder. J Affect Disord. 2013;151(2):722-727. 
262. Stanton R, Happell B. Exercise for mental illness: a systematic review of inpatient studies. Int J Ment Health Nurs. 2014;23(3):232-242.

263. Oertel-Knöchel V, Mehler P, Thiel C, et al. Effects of aerobic exercise on cognitive performance and individual psychopathology in depressive and schizophrenia patients. Eur Arch Psychiatry Clin Neurosci. Epub February 2, 2014.

264. Neeper SA, Gómez-Pinilla F, Choi J, Cotman C. Exercise and brain neurotrophins. Nature. 1995;373(6510):109.

265. Gustafsson G, Lira CM, Johansson J, et al. The acute response of plasma brain-derived neurotrophic factor as a result of exercise in major depressive disorder. Psychiatry Res. 2009;169(3):244-248.

266. Laske C, Banschbach S, Stransky E, et al. Exercise-induced normalization of decreased BDNF serum concentration in elderly women with remitted major depression. Int J Neuropsychopharmacol. 2010;13(5):595-602.

267. Yarrow JF, White LJ, McCoy SC, Borst SE. Training augments resistance exercise induced elevation of circulating brain derived neurotrophic factor (BDNF). Neurosci Lett. 2010;479(2):161-165.

268. Seifert T, Brassard P, Wissenberg M, et al. Endurance training enhances BDNF release from the human brain. Am J Physiol Regul Integr Comp Physiol. 2010;298(2):R372-R377.

269. Goekint M, De Pauw K, Roelands B, et al. Strength training does not influence serum brain-derived neurotrophic factor. Eur J Appl Physiol. 2010;110(2):285-293.

270. Schiffer T, Schulte S, Hollmann W, Bloch W, Strüder HK. Effects of strength and endurance training on brain-derived neurotrophic factor and insulin-like growth factor 1 in humans. Horm Metab Res. 2009;41(3):250-254.

271. Zoladz JA, Pilc A, Majerczak J, Grandys M, Zapart-Bukowska J, Duda K. Endurance training increases plasma brain-derived neurotrophic factor concentration in young healthy men. $J$ Physiol Pharmacol. 2008;59 Suppl 7:119-132.

272. Ferris LT, Williams JS, Shen CL. The effect of acute exercise on serum brain-derived neurotrophic factor levels and cognitive function. Med Sci Sports Exerc. 2007;39(4):728-734.

273. Schmolesky MT, Webb DL, Hansen RA. The effects of aerobic exercise intensity and duration on levels of brain-derived neurotrophic factor in healthy men. $J$ Sports Sci Med. 2013;12(3):502-511.

274. Wise LA, Adams-Campbell LL, Palmer JR, Rosenberg L. Leisure time physical activity in relation to depressive symptoms in the Black Women's Health Study. Ann Behav Med. 2006;32(1):68-76.

275. Babyak M, Blumenthal JA, Herman S, et al. Exercise treatment for major depression: maintenance of therapeutic benefit at 10 months. Psychosom Med. 2000;62(5):633-638.

276. Hoffman BM, Babyak MA, Craighead WE, et al. Exercise and pharmacotherapy in patients with major depression: one-year follow-up of the SMILE study. Psychosom Med. 2011;73(2):127-133.

277. Krogh J, Rostrup E, Thomsen C, Elfving B, Videbech P, Nordentoft M. The effect of exercise on hippocampal volume and neurotrophines in patients with major depression - a randomized clinical trial. $J$ Affect Disord. 2014;165:24-30.

278. Acheson A, Conover JC, Fandl JP, et al. A BDNF autocrine loop in adult sensory neurons prevents cell death. Nature. 1995;374(6521): $450-453$.

279. Choi SH, Li Y, Parada LF, Sisodia SS. Regulation of hippocampal progenitor cell survival, proliferation and dendritic development by BDNF. Mol Neurodegener. 2009;4:52.

280. Kazlauckas V, Pagnussat N, Mioranzza S, et al. Enriched environment effects on behavior, memory and BDNF in low and high exploratory mice. Physiol Behav. 2011;102(5):475-480.

281. Sun H, Zhang J, Zhang L, Liu H, Zhu H, Yang Y. Environmental enrichment influences BDNF and NR1 levels in the hippocampus and restores cognitive impairment in chronic cerebral hypoperfused rats. Curr Neurovasc Res. 2010;7(4):268-280.

282. Cotman CW, Berchtold NC. Exercise: a behavioral intervention to enhance brain health and plasticity. Trends Neurosci. 2002;25(6): 295-301.
283. Fang ZH, Lee CH, Seo MK, et al. Effect of treadmill exercise on the BDNF-mediated pathway in the hippocampus of stressed rats. Neurosci Res. 2013;76(4):187-194.

284. Noble EE, Mavanji V, Little MR, Billington CJ, Kotz CM, Wang C. Exercise reduces diet-induced cognitive decline and increases hippocampal brain-derived neurotrophic factor in CA3 neurons. Neurobiol Learn Mem. 2014;114C:40-50.

285. de Almeida AA, Gomes da Silva S, Fernandes J, et al. Differential effects of exercise intensities in hippocampal BDNF, inflammatory cytokines and cell proliferation in rats during the postnatal brain development. Neurosci Lett. 2013;553:1-6.

286. Aguiar AS Jr, Stragier E, da Luz Scheffer D, et al. Effects of exercise on mitochondrial function, neuroplasticity and anxio-depressive behavior of mice. Neuroscience. 2014;271:56-63.

287. Goda A, Ohgi S, Kinpara K, Shigemori K, Fukuda K, Schneider EB. Changes in serum BDNF levels associated with moderate-intensity exercise in healthy young Japanese men. Springerplus. 2013;2:678.

288. Suzuki G, Tokuno S, Nibuya M, et al. Decreased plasma brain-derived neurotrophic factor and vascular endothelial growth factor concentrations during military training. PLoS One. 2014;9(2):e89455.

289. Bos I, Jacobs L, Nawrot TS, et al. No exercise-induced increase in serum BDNF after cycling near a major traffic road. Neurosci Lett. 2011;500(2):129-132.

290. Tang D, Lee J, Muirhead L, et al. Molecular and neurodevelopmental benefits to children of closure of a coal burning power plant in China. PLoS One. 2014;9(3):e91966.

291. Babaei P, Azali Alamdari K, Soltani Tehrani B, Damirchi A. Effect of six weeks of endurance exercise and following detraining on serum brain derived neurotrophic factor and memory performance in middle aged males with metabolic syndrome. J Sports Med Phys Fitness. 2013;53(4):437-443.

292. John AP, Koloth R, Dragovic M, Lim SC. Prevalence of metabolic syndrome among Australians with severe mental illness. Med J Aust. 2009;190(4):176-179.

293. Christensen O, Christensen E. Fat consumption and schizophrenia. Acta Psychiatr Scand. 1988;78(5):587-591.

294. Molteni R, Barnard RJ, Ying Z, Roberts CK, Gómez-Pinilla F. A high-fat, refined sugar diet reduces hippocampal brain-derived neurotrophic factor, neuronal plasticity, and learning. Neuroscience. 2002;112(4):803-814.

295. Woo J, Shin KO, Park SY, Jang KS, Kang S. Effects of exercise and diet change on cognition function and synaptic plasticity in high fat diet induced obese rats. Lipids Health Dis. 2013;12:144.

296. Kaczmarczyk MM, Machaj AS, Chiu GS, et al. Methylphenidate prevents high-fat diet (HFD)-induced learning/memory impairment in juvenile mice. Psychoneuroendocrinology. 2013;38(9):1553-1564.

297. Yamada-Goto N, Katsuura G, Ochi Y, et al. Impairment of fear-conditioning responses and changes of brain neurotrophic factors in diet-induced obese mice. J Neuroendocrinol. 2012;24(8):1120-1125.

298. Yamada N, Katsuura G, Ochi Y, et al. Impaired CNS leptin action is implicated in depression associated with obesity. Endocrinology. 2011;152(7):2634-2643.

299. Peleg-Raibstein D, Luca E, Wolfrum C. Maternal high-fat diet in mice programs emotional behavior in adulthood. Behav Brain Res. 2012;233(2):398-404

300. Balogun KA, Cheema SK. The expression of neurotrophins is differentially regulated by omega- 3 polyunsaturated fatty acids at weaning and postweaning in C57BL/6 mice cerebral cortex. Neurochem Int. 2014;66:33-42.

301. Gama CS, Canever L, Panizzutti B, et al. Effects of omega-3 dietary supplement in prevention of positive, negative and cognitive symptoms: a study in adolescent rats with ketamine-induced model of schizophrenia. Schizophr Res. 2012;141(2-3):162-167.

302. Spencer JP, Vauzour D, Rendeiro C. Flavonoids and cognition: the molecular mechanisms underlying their behavioural effects. Arch Biochem Biophys. 2009;492(1-2):1-9. 
303. Jang SW, Liu X, Yepes M, et al. A selective TrkB agonist with potent neurotrophic activities by 7,8-dihydroxyflavone. Proc Natl Acad Sci US A. 2010;107(6):2687-2692.

304. Liu X, Chan CB, Jang SW, et al. A synthetic 7,8-dihydroxyflavone derivative promotes neurogenesis and exhibits potent antidepressant effect. J Med Chem. 2010;53(23):8274-8286.

305. Choi DC, Maguschak KA, Ye K, Jang SW, Myers KM, Ressler KJ. Prelimbic cortical BDNF is required for memory of learned fear but not extinction or innate fear. Proc Natl Acad Sci US A. 2010;107(6):2675-2680.

306. Choi DC, Gourley SL, Ressler KJ. Prelimbic BDNF and TrkB signaling regulates consolidation of both appetitive and aversive emotional learning. Transl Psychiatry. 2012;2:e205.

307. Andero R, Heldt SA, Ye K, Liu X, Armario A, Ressler KJ. Effect of 7,8-dihydroxyflavone, a small-molecule TrkB agonist, on emotional learning. Am J Psychiatry. 2011;168(2):163-172.

308. Andero R, Ressler KJ. Fear extinction and BDNF: translating animal models of PTSD to the clinic. Genes Brain Behav. 2012;11(5): 503-512.

309. Apawu AK, Maina FK, Taylor JR, Mathews TA. Probing the ability of presynaptic tyrosine kinase receptors to regulate striatal dopamine dynamics. ACS Chem Neurosci. 2013;4(5):895-904.

310. Ren Q, Zhang JC, Fujita Y, Ma M, Wu J, Hashimoto K. Effects of TrkB agonist 7,8-dihydroxyflavone on sensory gating deficits in mice after administration of methamphetamine. Pharmacol Biochem Behav. 2013;106:124-127.

311. Yang YJ, Li YK, Wang W, et al. Small-molecule TrkB agonist 7,8dihydroxyflavone reverses cognitive and synaptic plasticity deficits in a rat model of schizophrenia. Pharmacol Biochem Behav. 2014;122: 30-36.

312. Xu SL, Bi CW, Choi RC, et al. Flavonoids induce the synthesis and secretion of neurotrophic factors in cultured rat astrocytes: a signaling response mediated by estrogen receptor. Evid Based Complement Alternat Med. 2013;2013:127075.

313. Oh SB, Park HR, Jang YJ, Choi SY, Son TG, Lee J. Baicalein attenuates impaired hippocampal neurogenesis and the neurocognitive deficits induced by $\gamma$-ray radiation. Br J Pharmacol. 2013;168(2): 421-431.

314. Park SJ, Kim DH, Kim JM, et al. Mismatch between changes in baicalein-induced memory-related biochemical parameters and behavioral consequences in mouse. Brain Res. 2010;1355:141-150.

315. Rendeiro C, Foley A, Lau VC, et al. A role for hippocampal PSANCAM and NMDA-NR2B receptor function in flavonoid-induced spatial memory improvements in young rats. Neuropharmacology. 2014;79:335-344.

316. Williams CM, El Mohsen MA, Vauzour D, et al. Blueberry-induced changes in spatial working memory correlate with changes in hippocampal CREB phosphorylation and brain-derived neurotrophic factor (BDNF) levels. Free Radic Biol Med. 2008;45(3):295-305.

317. Yamamoto Y, Shioda N, Han F, et al. Nobiletin improves brain ischemiainduced learning and memory deficits through stimulation of CaMKII and CREB phosphorylation. Brain Res. 2009;1295:218-229.
318. Li F, Gong QH, Wu Q, Lu YF, Shi JS. Icariin isolated from Epimedium brevicornum Maxim attenuates learning and memory deficits induced by d-galactose in rats. Pharmacol Biochem Behav. 2010;96(3): 301-305.

319. Kreijkamp-Kaspers S, Kok L, Grobbee DE, et al. Effect of soy protein containing isoflavones on cognitive function, bone mineral density, and plasma lipids in postmenopausal women: a randomized controlled trial. JAMA. 2004;292(1):65-74.

320. Bagheri M, Joghataei MT, Mohseni S, Roghani M. Genistein ameliorates learning and memory deficits in amyloid $\beta(1-40)$ rat model of Alzheimer's disease. Neurobiol Learn Mem. 2011;95(3):270-276.

321. Xiong Z, Jiang B, Wu PF, et al. Antidepressant effects of a plantderived flavonoid baicalein involving extracellular signal-regulated kinases cascade. Biol Pharm Bull. 2011;34(2):253-259.

322. Yi LT, Xu HL, Feng J, Zhan X, Zhou LP, Cui CC. Involvement of monoaminergic systems in the antidepressant-like effect of nobiletin. Physiol Behav. 2011;102(1):1-6.

323. Li J, Zhou Y, Liu BB, et al. Nobiletin ameliorates the deficits in hippocampal BDNF, TrkB, and synapsin I Induced by chronic unpredictable mild stress. Evid Based Complement Alternat Med. 2013 ; 2013:359682.

324. Lv QQ, Wu WJ, Guo XL, et al. Antidepressant activity of astilbin: involvement of monoaminergic neurotransmitters and BDNF signal pathway. Biol Pharm Bull. 2014;37(6):987-995.

325. Wu X, Wu J, Xia S, Li B, Dong J. Icaritin opposes the development of social aversion after defeat stress via increases of GR mRNA and BDNF mRNA in mice. Behav Brain Res. 2013;256:602-608.

326. Ma X, Wang R, Zhao X, et al. Antidepressant-like effect of flaxseed secoisolariciresinol diglycoside in ovariectomized mice subjected to unpredictable chronic stress. Metab Brain Dis. 2013;28(1):77-84.

327. Al-Rahbi B, Zakaria R, Othman Z, Hassan A, Ahmad AH. Enhancement of BDNF concentration and restoration of the hypothalamic-pituitaryadrenal axis accompany reduced depressive-like behaviour in stressed ovariectomised rats treated with either Tualang honey or estrogen. Scientific WorldJournal. 2014;2014:310821.

328. Corona G, Vauzour D, Hercelin J, Williams CM, Spencer JP. Phenolic acid intake, delivered via moderate champagne wine consumption, improves spatial working memory via the modulation of hippocampal and cortical protein expression/activation. Antioxid Redox Signal. 2013;19(14):1676-1689.

329. Gomez-Pinilla F, Nguyen TT. Natural mood foods: the actions of polyphenols against psychiatric and cognitive disorders. Nutr Neurosci. 2012;15(3):127-133.

330. De Nicoló S, Tarani L, Ceccanti M, et al. Effects of olive polyphenols administration on nerve growth factor and brain-derived neurotrophic factor in the mouse brain. Nutrition. 2013;29(4):681-687.

331. Lardner AL. Neurobiological effects of the green tea constituent theanine and its potential role in the treatment of psychiatric and neurodegenerative disorders. Nutr Neurosci. 2014;17(4):145-155.

332. de Beaufort I. 'Please, sir, can I have some more?' Food, lifestyle, diets: respect and moral responsibility. Best Pract Res Clin Gastroenterol. $2014 ; 28(2): 235-245$.
Journal of Receptor, Ligand and Channel Research

\section{Publish your work in this journal}

The Journal of Receptor, Ligand and Channel Research is an international, peer reviewed, open access, online journal. The journal welcomes laboratory and clinical findings in the fields of biological receptors, ligands, channel and signal transduction research including: receptors and signaling ligands; transporters, pores and channels; binding and activation; receptor

\section{Dovepress}

regulation; role of receptors in diseases and their treatment; molecular basis of membrane structure and functions; molecular models of membranes. The manuscript management system is completely online and includes a very quick and fair peer-review system. Visit http://www.dovepress.com/ testimonials.php to read real quotes from published authors. 